próprio punho desse ato de última vontade do testador, sem testemunhas, que poderá ser confirmado a critério do juiz, no ato de publicação e registro judicial do testamento (art. 1.879).

$\mathrm{Na}$ ordem formal, o Projeto simplifica, sem comprometer a validade do ato, os requisitos exigidos pela codificação de 1.916. As três modalidades de testamento comum podem ser escritas manual ou mecanicamente, esta por qualquer instrumento mecânico, inclusive por digitação, desde que todas as páginas sejam numeradas e autenticadas com a assinatura do testador ou por quem a seu rogo o escrever (arts. 1.864 e 1.868, respectivos parágrafos únicos e art. $1.876, \S 2^{\circ}$ ). Os testamentos cerrado e particular podem ser escritos em língua estrangeira, naturalmente se o testador e as testemunhas forem versadas na língua escolhida (arts. 1.871 e 1.880 )

Quanto ao número de testemunhas que devem obrigatoriamente estar presentes no ato, o Projeto as reduziu para duas, no testamento público e no cerrado, as cinco testemunhas exigidas pelo Código vigente (arts. 1.864, I e
1.868, I) e para três, pelo menos, no testamento particular (art. 1.878, $\S 1^{\circ}$ ), quando para esta modalidade são também exigidas cinco no estatuto de 1.916. Para a modalidade especial de testamento marítimo são exigidas duas testemunhas, como na codificação anterior e para a outra modalidade especial do testamento aeronáutico, ora criada, as mesmas duas testemunhas (art. 1.888), enquanto que, para a modalidade especial do testamento militar, são mantidas as duas testemunhas exigidas no estatuto anterior, ou três, se o testador não puder ou não souber assinar, caso em que assinará por ele uma das testemunhas (art. 1.893).

Aqui, nesta breve exposição, apresentada de maneira sumária por exigência de espaço no período em que será publicada traz-se a notícia dos novos institutos da or dem civil moderna, acolhidas pelo Projeto, e bem assim as principais modificações supressões dos contemplados na codificação de 1.916, com o escopo de substituí-la em sua integralidade por um novo estatuto consentâneo com as conquistas humanas, sociais, culturais e econômicas da Nação.

\section{Relações de Consumo na pós-modernidade: Em defesa de uma interpretação finalista dos Artigos 2o e 29 do $\mathrm{CDC}^{1}$}

\author{
Claudia Lima Marques
}

Professora da Universidade Federal do Rio Grande do Sul, Doutora em Direito pela Universidade de Heidelberg, Alemanha. Mestre em Direito pela Universidade de Tübingen e Especialista em Integração Européia pelo Europa-Institut, Saarbrücken, Alemanha
INTRODUÇÃO

Neste belo encontro sobre os Desafios do direito atual, gostaria de aprofundar a análise do campo de aplicação do $\mathrm{CDC},{ }^{2}$ concentrando-me em dois aspectos ainda polêmicos das relaçōes de consumo e que me parecem decisivos na prática: no campo de aplicação subjetivo do CDC, a ainda viva discussão sobre o sujeito de direito consumidor, e, em especial, so- bre quais os critérios usados para a identificação deste sujeito tutelado na doutrina e na jurisprudência, mister, pois, analisar este novo sujeito pós-moderno de direitos, o consumidor, destacar sua pluralidade, fluidez e finalismo impostos pela técnica do CDC, propondo critérios, ao mesmo tempo, atualizados e sólidos para sua identificação nas relçaões de consumo (Parte $I)^{3}$ e, no campo de aplicação material do CDC, útil parece-me uma reflexão mais detida sobre
Versão atualizada da palestra apresentada no Seminário "Desafios do Direito Contemporâneo" do Mestrado em Direito da Faculdade de Campos (RJ), 1999. A autora agradece à Profa. Dra. Rosangêla Lunardelli Cavallazzi e ao Prof. Dr. Gustavo Tepedino as instigantes discussóes sobre o tema e o agradável e estimulante trabalho conjunto na cadeira "Relaçôes de consumo" no Mestrado Acadêmico de Campos.

2 Em meu artigo, "Proposta de uma teoria geral dos serviços com base no Código de Defesa do Consumidor - A evolução das obrigações envolvendo serviços remunerados direta ou indiretamente", publicada em Revista Direito do Consumidor, vol. 33 (2000), p. 79 a 122, analisei as relaçóes de consumo, com especial Revista Direito do Consumidor, vol. 33 (200), $p .79$ a 122 , analisei as relaçóes de consumo, com especial
ênfase nas prestaçóes envolvendo de servicos, analisando seus elementos intrínsecos, a nova noção de obrigação, total e cooperativa, a idéia de vinculação própria por atos pré-negociais e os seus elementos externos, os sujeitos (consumidor e fornecedor), o objeto, e a finalidade destas relaçóes de consumo como reguladas pelo Código de Defesa do Consumidor.

3 Esta parte da exposição será desenvolvida também para o V Congresso Brasileiro de Direito do Consumidor, a acontecer em Belo Horizonte, de 2a 5 de maio, a ser publicada em seus anais como título: 'Direitos básicos do consumidor na sociedade pós-moderna de serviços: o aparecimento de um sujeito novo e a realização de seus direitos", ainda inédito.

Revista da Faculdade de Direito da UFRGS, v. 19, Março/2001 
as relações de consumo envolvendo serviços, em especial o seu objeto e finalidade, uma vez que tratam-se hoje de relações complexas, com múltiplas e conexas prestações, e que se analisadas superficionalmente, poderiam até ser consideradas relações gratuítas frente ao consumidor-vítima, apesar do serviço ser em si "remunerado", direta ou indiretamente, como exige o CDC para sua aplicação(Parte II). ${ }^{4}$

A relação de consumo é intrinsicamente "relacional", ${ }^{5}$ isto é, depende da presença simultânea de dois agentes especiais interagindo, um consumidor e um fornecedor, ${ }^{6}$ e é "finalistica", pois concretiza-se na sua causa, causa inicial e final, na sua finalidade, que é naturalmente de consumo. Segundo ensina Nelson Nery Júnior, o objeto "de regulamentação pelo Código de Defesa do Consumidor é a relação de consumo, assim entendida a relação jurídica existente entre fornecedor e consumidor tendo como objeto a aquisição de produtos ou utilização de serviços pelo consumidor.... São elementos da relação de consumo, segundo o $C D C:$ a) como sujeitos, o fornecedor e o consumidor; b) como objeto, os produtos e serviços; c) como finalidade, caracterizando-se como elemento teleológico das relações de consumo, serem elas celebradas para que o consumidor adquira produto ou se utilize de serviço 'como destinatário final'(Art2 2,caput última parte, CDC."”

Em resumo, na relação de consumo es cos específicos, agentes que a lei denomina de tos ou serviços e "consumidor", o outro, aquele destinatário final do produto ou do serviço (Art 2 do $\mathrm{CDC}$ ) ou aqueles a ele equi parados ( $\mathrm{Pa}$ rágrafo único do Art. $2^{\circ}$, Art. $17 \mathrm{e}$ Art. 29 do CDC). O campo de aplicação do CDC é, portanto, especial, no que se refere aos sujeitos (ratione personae) e geral, no que se refere ao contratos em espécie (ratione materiae), incluindo as relações envolvendo serviços em geral, e as especialmente mencionadas atividades de natureza bancária, financeira, de crédito securitária, excluídas apenas as relações de caráter trabalhista (Art. $3^{\circ} \S 2^{\circ}$ do CDC) .Analisaríamos neste artigo, pois, dentre os elementos externos das relações de consumos, nos sujeito da relação, apenas o consumidor (Parte I), objeto e a finalidade da relação de consumo envolvendo serviço (Parte II), deixando de ana lisar o sujeito fornecedor, o objeto das relaçōes de fornecimento de produtos e o elemento forma. ${ }^{8}$

A opção pela estudo apenas das relações de consumo envolvendo serviços é oportuna, pois permite uma análise pós-moderna. ${ }^{9}$ tão presentes, relacionando-se, atores econôm"fornecedor", o profissional que fornece produ-

4 Sobre este tema, iniciamos as reflexões no referido artigo, Proposta de uma teoria geral dos serviços com base no Código de Defosa do Consumidor - A evolucão das obrigacões envolvendo serviços remunerados

direta ou indiretamente, que nos servirá de base.
Assim concorda Antonio Janyr DALL'AGNOL, citando Fábio Ulhoa COELHO, in Direito do consumidor Janyr DALLAGNOL, citando Fibio Lin e serviços bancários e financeiros - Aplicação do CDC nas atividades bancárias, in Revista Direito do
Consumidor, vol. 27 (1998), p. 9 .

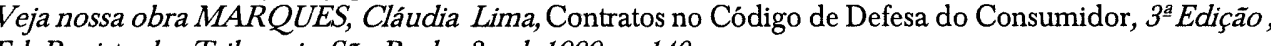
Ed. Revista dos Thibunais, São Paulo, 3. ed.,1999, p. 140 e seg.

Congo Brasileiro de Defesa do Consumidor- Comentado pelos Autores do Anteprojeto, Ada Pellegrini Grinover et al., Ed. Forense Universitária, Rio de Janeiro, 1998, p. 342

Nestes pontos, remeto-me às análises já realizadas em nosso artigo, , Proposta de uma teoria geral dos serviços, vol. 33 (2000), p. 79 a 122.

Esta análise pós-moderna é uma homenagem ao mestre orientador de Doutorado, Prof. Dr. Dr.h.c. Erik Jayme, da Universidade de Heidelberg, que em seu brilhante curso de Haia lançou sua teoria dos reflexos da pós-modernidade no direito que agora trazemos para o direito civil e expandimos, com a devida vênia. Veja $J A Y M E$, Erik, Identité culturelle et intégration: Le droit internationale privé postmoderne - in: Recueil des Cours de l' Académie de Droit International de la Haye, 1995,II, pg. 36 e seg.

Revista da Faculdade de Direito da UFRGS, v. 19, Março/2001
Hoje o economicamente relevante, na sociedade atual, é prioritariamente, o imaterial, os fazeres e serviços complexos do novo mercado brasileiro. ${ }^{10}$ Seria inútil, porém, analisar estas relações de consumo fora de seu contexto atual (pós-moderno). Eis, porque, queremos analisá-las no contexto da sociedade brasileira deste final de século XX, pois como afirma o título deste conclave, este é o desafio do direito atual, em uma década evoluímos da

10 Veja minha obra Contratos no Código de Defesa do Consumidor, 3. ed. São Paulo, Ed. RT, 1999, p. 89 e seg. Nesta, defendo a idéia que a crise da pós-modernidade no direito advém também da modificação dos bens economicamente relevantes, que na idade média eram os bens imóveis, na idade moderna, o bem móvel material e que na idade atual seria o bem móvel imaterial ou o desmaterializado "fazer" dos serviços, do soft ware, da comunica̧̧ão, do lazer, da segurança, da educação, da saúde, do crédito. Se são estes bens imateriais e fazeres que sấo a riqueza atual, os contratos que autorizam e regulam a transferência destas imateriais e fazeres que sấo a riqueza atual, os contratos que autorizam e regulam a transferência destas
"niquezas" na sociedade também têm de mudar, evoluir do modelo de dar da compra e venda para modelos "niquezas" na sociedade também têm de mudar, evoluir do modelo de dar da compra e venda para mode

"novos de serviços e dares complexos, adaptando-se a este desafio desmaterializante "pos-mo Cormo. Sobre o fordismo do "consumismo" e da produçāo de bem móveis
La Postmodernidad juridica, Ed. Gowa, Buenos Aires, 1995,p. 53 .

12 Sobre o tema veja a interessante análise do jus-filósofo argentino Ciúro Caldani, Miguel Angel, La debilidad del consumidor en la sociedad de consumo, in Investigación y Docencia, nr. 28 (Rosário, Ed. FI), 1997, p. 33 e seg.

13 Veja sobre "desmaterializaçâo" nosso livro, Contratos, $p$.. 89 e seg. Os sociólogos preferem estudar o fenômeno na mudança dos meios de produção: préindustrial, industrial e pósindustrial ou informacionalismo (informationalism), veja Castells analisando os ensinamentos de Tourraine, Castells, Manuel The rise of the network society, voll, The Information age: economy, society and culture, Blackwell, Massachusetts, 1996/1999, p. 14 e seg.

14 Escolhemos a expressão "nivelamento" para denominar esta nova forma de universalismo cultural despersonalizador causado ou potencializado pela globalização e não homogeneização, em virtude das críticas de Featherstone, Mike, "Cultura global:Introduçao", in Featherstone, Mike (Org.), Cultura Global, Vozes, Petrópolis, 1994, p. 8: “O pós-modernismo é ao mesmo tempo um símbolo e uma poderosa imagem cultural do desvio da conceptualização da cultura global, menos em termos dos alegados processos de homogeneização (por exemplo, teorias que apresentam um imperialismo cultural, americanização e uma cultura de consumo de massa como cultura proto-universal que se propaga às expensas da dominação econômico-política do Ocidente), e mais em termos de diversidade, de variedade e da niqueza dos discurso populares e locais, dos códigos e das práticas que resistem e produzem a sistematização e a ordem."

${ }_{15}$ Sobre o pósfordismo dos servicos, dos fazerese "dares" de bens imateriais, veja Ghersi, La posmodernidad, $p$. 48 a 55.
${ }_{16}$ Sobre o significado nova da "identidade" na "network society", veja os ensinamentos de Castells, Manuel, The Power of Identity, vol. II "The information age: economy, society and culture", Blackwell, Massachusetts 1997, p. 6: "Byidentity, as it refers to social actors. Iunderstand the process of constuction of meaning on the 1997, p. 6: "Byidentity, as it refers to social actors, I understand the process of constuction of meaning on the basis of a cultural attributes, that is/are given priority over other sources of meaning." Sobre identidad cultural como instrumento de renascimento do direito, veja Jayme, p. 56 e seg.

Veja comparando a hierarquia feudale violenta da idade média às áreas pobres latinoamericanas, Calderón Fernando Latin American Identity and Mixed Temporalities; or How to Be Postmodern and Indian at the Same time, in The Postmodernism Debate in Latin America, Duke University Press, Durham, 1995,p. 56 e seg.

Sobre exclusão e marginalidade como consequêencias de nosso tempo, veja a socióloga gaúcha Soares, Maria Suzana Artosa, Editorial do número especial "Modemidade" da Revista Cadernos de sociologia/UFRGS, nr. 5, vol.5, 1993, p.1.

19 Para uma análise mais econômica da mudança do paradigma fordista para o pósfordista e seus reflexos no direito e na sociedade de consumo, veja o mestre argentino Ghersi, La posmodernidad, $p .27$ e seg. e sobre os reflexosno contrato, do mesmo autor, Tercera Via-Âmbito jurídico, Gowa, Buenos Aires, 2000, p. 49 e seg.

Revista da Faculdade de Direito da UFRGS, v. 19, Março/2001 
Mister, pois, analisar estas relações de das as ciências, em especial na nossa ciência consumo conscientes da crescente crise da pósmodernidade, ${ }^{20}$ do perigo de desconstrução de nossa ciência do Direito ${ }^{21}$, de desregulamentação e de deslegitimação de nossas instituições, ${ }^{22}$ da necessidade da re-construção de uma doutrina e de uma prática mais adaptada aos desafios atuais da sociedade "desmaterializada",

"despersonalizada" e globalizada dos serviços. ${ }^{23}$

A crise da pós-modernidade que vivenciamos é uma crise social. Não é diretamente crise do direito, mas tem reflexos em toAssim um dos grandes filosofos da pós-modernidade,escrevendo sobre "Postmodernism and consumer
society",Jameson, Frederic, The cultural Turn - Selected Writings on the Postmodern,1983-1998, Verso, society", Jameson, Frederic,
Londres, 1998, p. 1 a 20.

2t Sobre a crise da ciência do direito, veja Rosenau, Pauline Marie, Post-modernism and the social sciences, Princeton University Press, Princenton, 1992, p. 71 e seg.

Descontrução é a palavra do momento, o reflexo mais visível do discurso e da filosofia pós-moderna $V$ Veja textos de bolso dos fllófos franceses, Postmoderne und Dekonstruktion, Texte französicher Philosophen der Gegenwart, Ed. Reclam, Stuttgart, 1990) inclusive no direito, veja sobre a geração "desconstrucionalista" da escola norte-americana Critical Legal Studies, Minda, Garry, Postmodern Legal Movements- Law and Jurisprudence at Century's end, New York University Press, New York, 1995, p. 116 e seg. Veja sobre os reflexos na pesquisa e na ciência do direito, meu artigo A crise científica do Direito na pós-modernidade e seus reflexos na pesquisa, in Cidadania e Justiça-Revista da AMB, ano 3, nr. 6 (1999), p. 237 e seg. (republicado na Revista Arquivos do MJ e pela editora da UFRGS).

alerta mais contudente é de Rosenau, p. 50,91 e 124: "Post-modernists in almost every field of the social sciences have been experimenting with a subjectless approach in their inquiries...Post-modernists reduce fragment these disciplines altogether. It is far from evident that replacing conventional social science fragment these disciplines altogether...It is far from evident that replacing conventional social science
methodology with post-modern methos of interpretation and deconstruction constitutes any improvement in
the social sciences"

${ }_{24}$ Assim Rosenau, p. 124: "Legal theory is an arena where post-modern views of epistemology and method have created one of the most serious intellectual crises, questioning the very legitimacy of judicial systems and the integrity of legal studies."

Como explica Featherstone, p. 17, qualquer referência à pós-modernidade imediatamente expõe $o$ autor a críticas, criticas de estar "na moda", de estar "Ultrapassado pelo pos-pos-modernismo, de usar "palavra sem sentido", de definíla de forma "errada", de "exagerar" seu uso, de "menosprezar" seu uso, enfim, críticas de todos os sentidos e matizes. (Featherstone, Mike, Cultura de Consumo e pós-modernismo, Trad. Júlio Assis Simóes, Studio Nobel, São Paulo, 1995, p. 17)

26 Esta reação "afirmativa" e de "reconstruçãà" já defendemos em dois artigos, A crise.., in Cidadania e JustiçaRevista da AMB, ano 3, nr. 6 (1999), p. 237 e seg.

Segundo Pauline Marie Rosenau ROSENAU, Pauline Marie, Post-modernism and the social sciences, rector ciências sociais, dois tipos de reaçoes estão acontecendo, há os que descontroem as teorias antes gerais, criticam severamente as soluçóes
universalistas, mas acabam paralisados, minoritários, a utilizar os mesmos instrumentos jurídicos dos séculos

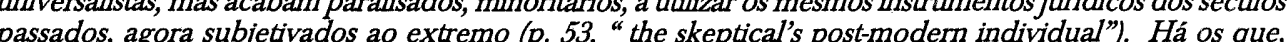
saudosos de algumas certezas da modernidade, procuram reconstruir as teorias em novas narrativas, frisam o diálogo de fontes, constatam a existência de novos paradigmas e verdades, verdades que mesmo mais tolerantes, fluf́las, menos universais e agora microsistêmicas, povoam de sentido o ordenamento atual ( $p$. 57, "affirmative post-modernists). Aos primeiros, denominou a autora pos-modernos cépticos, os segundos, pósmodemos afirmativos, e fotografou assim a crise atual de nassa ciência: conclundo que somente após retomar ao estudo do objeto (que poderia ser, em nosso caso, a Justica ao consumidor de serviços no Brasil) é que a abalada ciência, o Direito, poderia, enfim, revitalizar-se (p.57).

Revista da Faculdade de Direito da UFRGS, v. 19, Març/200 fracos na sociedade de consumo, daí a importância do estudo do sujeito tutelado, o consumidor. Esta consciência e receio é que devem guiar-nos para uma interpretação, concreção aplicação do CDC cada vez mais voltadas para a realização dos seus princípios motores e do ideais antigos e atuais de igualdade material de desiguais, de liberdade racional e informada, $d$ solidariedade e Justiça distributiva no mercado. ${ }^{2}$ Apesar da complexidade das relações atuais do sistema do Direito, há que prevalecer uma ética reconstrutiva, ${ }^{29}$ uma dogmática renovada ${ }^{30}$ e uma interpretação protetiva e útil para este agente econômico privilegiado, o consumidor modo a tornar eficaz o CDC e o Direito do Consumidor.

I - AS PLURAIS DEFINIÇÕES DE CONSUMIDOR NO CDC: ENTRE PÓSMODERNIDADE E INTERPRETA ÇÃO FINALISTA

O novo do CDC é ter identificado este

sujeito de direitos, o consumidor e ter construído um sistema de normas e princípios orgânicos para protegê-lo e efetivar seus direitos ${ }^{31} \mathrm{~A}$ identificação deste novo sujeito de direitos, deste grupo de não-iguais, de vulneráveis parece-me ter fortes conotações pós-modernas. ${ }^{32}$ No caso brasileiro, trata-se da realização de um direito fundamental (positivo) de proteção do Estado ${ }^{33}$ para o consumidor (Art. 5, XXXII da CF/88). O consumidor foi identificado constitucionalmente (Art. 48 do ADCT) como agente a ser necessariamente protegido de forma especial.

A.Crise da pós-modernidade e a pluralidade de sujeitos

Se desejamos verificar se o consumidor, se este sujeito de direitos "novo", possui as qualidades de um sujeito de direitos pós-moderno, e estaria adaptado ao atual pluralismo de sujeitos e de leis, mister analisar a crise da pósmodernidade e seus reflexos no direito . Para conduzir esta análise iremos nos basear na teo-

Es Em sua obra Beyond Interpretation, Gianni Vattimo propugna a volta da hermenêtica a seus ideais antigos como forma de reconstruir a fllosofia e as ciências sociais: "The task of contemporary hermeneutics seems to be that of articulating in an ever more complete and explicit form this original inspiration " Vatimmo, Gianni, Beyond Interpretation - The Meaning of Hermeneutics for Philosophy, Stanford University Press, Stanford, 1997, p. 111). Assim propugna também Leonard, Peter, Postmodern Welfare- Reconstructing an Emanci patory Project,
Sage Publications, Londres, 1997, p.164: "If we are to pursue the idea that welfare has an enacipatory potential as yet only half-revealed in the modern welfare state, then we must consider how we are to pavigate our way through the turbulent waters produced by two mo, lobligations which in pratice have often stood in conflict with each other: to difference and to by idarity" Assim também

Assim também Ladeur, Karl-Heinz, Superamento della complessitá attraverso la capacitá di apprendimento discorso di Jüreguamento del diritto alle condizioni del Postmoderno. Una critica alla teoria giuridica del discorso di Jürgen Habermas, in Rivista Internazionale de Filosofia del Diritto, IV série, V. LXXII, n. 3, Veja sobre o tema

Revis sobre o tema, menção de Azevedo, Antonio Junqueira de, O Direito pós-moderno e a codificação, in Revista Direito do Consumidor, vol, 33 (2000), p. 124.

Assim identifica Minda, p.74, o início da descontrução da "modern jurisprudence" e dos "postmoderne legal movements" justamente na decisão da Suprema Corte americana no caso Brown, sobre direitos iguais das pessoas de raças diferentes:" "In Brown, the Supreme. Court rejected the theory of separate but equal because legal analysis had failed to take into account inequality arising from cultural context, and because the

theory itself failed to take account of the role law played in reinforcing the cultural values of race discrimination." Sobre tema do direito a alguna Handlungen), veja Alexy, p. 179 e seg.

Revista da Faculdade de Direito da UFRGS, v. 19, Março/200 
ria de Erik Jayme ${ }^{34}$ sobre os reflexos da cultura pós-moderna no direito atual.

Como afirmamos anteriormente, o pósmodernismo é uma crise de desconstrução, de desdogmatização do Direito, ${ }^{36}$ para outros, é um fenômeno de pluralismo e relativismo cultural arrebatador a influenciar o Direito, ${ }^{37}$ que aumenta a liberdade dos individuos ${ }^{38}$ mas $\mathrm{d}$ minui o poder da crítica, da evolução históri$\mathrm{ca}^{39}$ e da verdade no Direito, ${ }^{40}$ fenômeno contemporâneo à globalização ${ }^{41}$ e à perda da individualidade moderna ${ }^{42}$, mas que assegura novos Direitos individuais à diferença ${ }^{43}$ e aumenta o radicalismo ${ }^{44}$ das linhas tradicionais. A pós modernidade é um jogo de palavras, um con-

ceito aberto, para alouns até mesmo inexistente, uma moda, "postis" como afirma Habermas. ${ }^{45}$ Particularmente, parece-me ser apenas uma tentativa, uma denominação sucinta para descrever a crise deste final de século nas artes, na cultura, nảs ciências ${ }^{46} \mathrm{em}$ geral e'no Direito em especial, e as modificações contrárias ou "posteriores" aos ideais do Direito moderno de igualdade, liberdade e fraternidade. E uma tentativa de descrever o grande ceticismo, o fim do racionalismo, o vazio teórico, a insegurança jurídica que se observam efetivamente na sociedade, no modelo de Estado, nas formas de economia, na ciência, nos princípios e nos valores de nossos povos nos dias atuais. ${ }^{47}$ Os pensadores europeus estão a denominar este momento de rom-

34 Veja Curso de Haia, p. 36 e seg. Veja do mesmo autor seu artigo sobre Direito Comparado pós-modemo, publicado na Revista dos Tribunais nr. 759, janeiro 1999, p.24 a 40, Visões para uma teoria pós-moderna do Direito Comparado . Veja também de minha autoria, utilizando sua teoria, os artigos, in Revista Direito do Consumidor, vol 22, pg. 64-86, Contratos de time-sharing e a proteção dos consumidores: crítica ao direito civil em tempos pós-modernos $e$ in Revista Direito do Consumidor, vol. 25, pg. 19-38, Contratos bancários em tempos pós-modernos- primeiras reflexões.

${ }^{35}$ Assim CARTY, Anthony (Ed.), Post-Modern Law, Edimburg, Univ. Press, _1990, p. viii: "Pos-modernism

* as a method of legal decontruction can as well be applied to the English and other legal orders."

$37 \frac{\text { SANT }}{\text { Assim, JAYME, p. } 36 \text { e seg. Veja sobre cultura e Direito LOPES, José Reinaldo de Lima, Direito e }}$ Assim, JAYME, p. 36 e seg. Veja sobre cultura e Direito LOPES, José Reinaldo de Lima, Direito e
Transformação Social, Belo Horizonte, Ed. Nova Alvorada, 1997,p. 77. Veja também nosso Artigo. Cem anos de BGB e o Código Civil Brasileiro, in Revista dos Tribunaus vol. 741.p. 21 e seg.

* FRIEDMAN. Lawrence, The Republic of Choice, Cambridge, Harvard University Press, 1994, p. 61.

VATTIMO Gianni, O fim da modernidade-niilismo e hermenêutica na cultura pós-moderna, São Paulo, Martins Fontes, 1996, p. XII.

- FOUCAULT Michel, La verdad y las formas jurídicas, Ed. Gedisa, 4 R., Barcelona, 1996, p. 80.

"I LAYME, Curso, p. 36.

GHERSL La posmodemidad 56 menciona relacōes economicas sem sujeito relacōes de orupos.

A $I A Y M E$ Curso, p. 37 .

${ }_{4}$ GELLNER. Ernest, Pós-modernismo, Razão e Religião, Instituto Piaget, Lisboa, 1992, p.,11.

${ }^{4}$ Como afirma Habermas, reconhecer, nomear ou denominar um fenômeno, como se faz com o pósmodernismo, significa se distanciar suficientemente deste e, mesmo, decretar o seu fim. Habermas não se considera pós-moderno, está comprometido com os ideais da modernidade, chega a ironizar a freqüente utilização na literatura atual desta denominação "pós", mas, por fim, reconhece a importância destes pensadores como sensiveis indicadores do "Zeitgeist", do pensamento e espírito atual a indicar uma mudança, assim HABERMAS, Jürgen, Nachmetaphysisches Denken, Ed.Suhrkamp, Frankfurt, 1992, p. 12.

46 Veja HARVEY, David, The Condition of Postmodernity - An enquiry into the Origins of Cultural Change, Cambridge/Massachusetts 1994, p. 3 a 42 e KAUFMANN, Arthur, Grundprobleme der Rechstphilosophie, München, Beck, 1994, p. 224 e seg.

Como explica Vattimo em sua introdução, "O pós de pós-moderno indica, com efeito, uma despedida da modernidade...", veja VATTIMO, 1996, p. VIL

Revista da Faculdade de Direito da UFRGS, v. 19, Março/2001 pimento (Umbruch), de fim de uma era e de início de algo novo, ainda não identificado. ${ }^{48}$ Chame-se como desejar o momento atual de crise e de mudança, a sua realidade supera qualquer expectativa ${ }^{49}$ e seus reflexos no Dire to ${ }^{50}$ não podem mais ser negados.

1. O aparecimento de um novo sujeito a interpretação de sua codificação es pecial

Interessante observar que as primeiras análises dos reflexos da crise da pós-modernidade na sociedade de consumo $0^{51}$ indicavam que a despersonalização das relações, iniciada com as relações massificadas de adesão e métodos mecânicos de contratação, levaria ao nascimento de "contratos sem sujeito" 52 ou mesmo de uma decantada "morte do sujeito" 53 , em uma desconstrução total deste sujeito. ${ }^{54}$ Certo é que

as noções de indivíduo e sujeito mudaram,,$^{55}$ mas também mudou nosso direito e nossa maneira de ver o sujeito: o sujeito de direitos está lá, não morreu, nem desapareceu, foi "resignificado". ${ }^{66}$ Parece-nos que, ao contrário, este sujeito qualificou-se com direitos, ${ }^{57}$ multiplicou-se, hoje são muitos sujeitos individuais, sujeitos homogêneos, coletivos e difusos, em um novo pluralismo de sujeitos que não impede que recebam e exerçam - diretamente ou através de representantes- seus direitos. Aceita esta premissa, interessa-nos, a afirmação de Erik Jayme que o sujeito de direitos identificado na pósmodernidade, qualifica-se quando recebe direitos fundamentais e acaba por modificar as instituições em que está. ${ }^{58}$

Sobre este sujeito novo de direitos, que é o consumidor poderíamos inicialmente frisar que como sujeito de direitos apareceu não faz muito tempo. Surgiu nos anos 60-70, identifica-

Veja LYOTARD, Jean-François, Das postmoderne Wissen - Ein Bericht, [Aus dem Französischen von Otto Pfersmann], Viena, Ed. Passagen, 1994, p. 13.

TOURRAINE, Alain, Uma Visão Crítica da Modernidade, in Cadernos de Sociologia/ UFRGS, vol. 5, 1993, 1995, pg. 37.

so GHERSI, La posmodernidad, pg. 27.

sl Como ensina Tourraine, Alain, Crítica da Modernidade, Instituto Piaget, Lisboa, 1994, p. 304, a sociedade de consumo e a sociedade de informação "fizeram nascer um individualismo que se opốe mais eficazmente, hoje em dia, à idéia de sujeito do que o antigo poder absoluto da razão"

A experssão é criaçâo de Ghersi, La postmodernidad, p. 56.

A expressão "the death of the subject" é usada por Jamenson, p. 5, mas no sentido-não de objetoftema-mas de sujeito ou de "end of individualism as such".

Veja, muito crítico quanto à veracidade histórica deste decantado (e cínico) discurso pós-moderno de descontrução, Bewes, Timothy, Cynism and Postmodernity, Verso, London, 1997, p. 45 e seg.

Esta é a conclusão de Jamenson, p. 6 e Ghersi, La postmodernidad, p. 56.

Sa literatura estrangeira, veja o tomo 34 dedicado ao tema (Le sujet de droit) dos Archives de Philosophie du Droit, Sirey Ed, Paris, 1989

57 Esta é a interessante proposta da Leonard, p. 32 e seg, de reconstruçâo do sujeito através de um projeto que chama de "antecipatório", como a protegêlo das pressóes do mundo atual, como a qualificar sua autonomia de vontade, agora informada e protegida, como a garantílo dos riscos múltiplos e complexos de nossa sociedade para que possa nela bem (e racionalmente...) contratar. sobre autonomia racional (tese de Chardin), veja nosso artigo Os contratos de crédito e a legislacão brasileira de proteção do consumidor, publicado na Revista Direito do Consumidor, vol 18, pg. 53-76. Revisa Dirello do Consumer, vol 18 pr. 53.76 .

Esta foi a afirmação básica de seu curso "Direito Patrimonial de Família na pós-modernidade", em 1996, na Faculdade de Direito da Universidade Federal do Rio Grande do Sul, ainda inédito. Veja também, no mesmo sentido geral, sobre respeito ao indivíduo e seus direitos humanos, Jayme, Curso, p. 49 e seg.

Revista da Faculdade de Direito da UFRGS, v. 19, Março/2001 
do então entre os contratantes, como cliente, como comprador, como aquele que é o transportado, o locatário, o mutuário, enfim, aquele cliente bancário e securitário, beneficiário, contratante ou terceiro-vítima.

Do seu aparecimento nos Estados Unidos levou certo tempo para "surgir" legislativamente no Brasil, apesar de ter conquistado facilmente a Europa e todos os países capitalistas da época. ${ }^{59}$ Dai a importância da Constituição de 1988 ter reconhecido este novo sujeito de direitos, assegurado sua proteção (Art. 5, XXXII e Art. 170, inciso V da CF/88) e mandado (Gebot) legislar sobre seus direitos (Art. 48 dos ADCT). $\mathrm{O}$ artigo $5^{\circ}$ estabelece como direito fundamental do cidadão brasileiro, a defesa dos seus direitos como consumidor. $\mathrm{O}$ artigo 170 estabelece que a ordem constitucional econômica do nosso mercado será baseada na livre iniciativa (caput), mas limitada pelos direitos subjetivos do consumidor (inciso V). Hoje, te direitos constitucionais assegurados é ter liber- dades e garantias especiais. ${ }^{60}$

A Constituição de 1988 é, pois, a origem da codificação tutelar dos consumidores no Brasil. Esta lei protetiva é uma micro-lei, lei privilegiadora, microsistema ${ }^{61}$ que acaba por abalar ou pelo menos modificar o sistema geral a que pertencia o "novo" sujeito, o Direito Privado. Trata-se da necessária concretização do Princípio da Igualdade, de tratamento desigual aos desiguais, da procura de uma igualdade material e momentânea para um sujeito com direitos diferentes, sujeito vulnerável, o mais fraco. ${ }^{62}$ Note-se que a lei especial e os direitos a ele assegurados são aqui instrumentos de Igualdade. ${ }^{63}$

Segundo Erik Jayme, ${ }^{64}$ os direitos humanos seriam as novas "normas fundamentais" 65 e estes direitos constitucionais influenciariam o novo direito civil, a ponto do Direito assumir um novo papel social, como limite, como protetor do indivíduo e como inibidor de abusos. ${ }^{66}$ A teoria elaborada por Erik Jayme é coinciden- s Sobre a evolução no direito comparado e a tramitação do projeto no Brasil, veja a introdução de Ada Pellegrini Grinover e Antônio Herman Benjamin, Código Brasileiro de Defesa do Consumidor comentado pelos Autores do Anteprojeto, Ed. Foresnse Universitária, Rio de Janeiro, 6.ed., 1999, p. 1 a 13.

\& Na expressão de Alexy, estes direitos asseguram/garantem/estimulam a efetivação da Dignidade do Homem, sua Liberdade e Igualdade ("... was die Verwirklichung von Menschenwürde, Freiheit und Gleichheit fordert"), ALEXY, Robert, Theorie der Grundrechte, Suhrkamp, Frankfurt, 1996, p.15.

6t Segundo Filomeno, o CDC é um microsistema jurídico de caráter inter e multidisciplinar, FLLOMENO, José Geraldo Brito, Código Brasileiro de Defesa do Consumidor comentado pelos autores do Anteprojeto, Ed. Foresnse Universitária, Rio de Janeiro, 6.ed., 1999, p. 19

a2 Veja ALEXY, p. 357 e seg., sobre o direito de igualdade e o mandamento de tratamento desigual dos desiguais, p. 371 e seg.

a Veja ALEXY, p. 410 e seg., sobre o direito à uma ação positiva (e protetiva) do Estado.

${ }^{6}$ JAYME, Erik, Identité culturelle et intégration: Le droit internationale privé postmoderne - Cours général de droit international privé 1995,in: Recueil des Cours de l'Académie de Droit International de la Haye, 1995,II, p. 37 .

${ }_{65}$ Assim LORENZETTI, Ricardo Luis, Fundamentos do Direito Privado, Ed. Revista dos Tribunais, 1998, p. 249 e seg.

${ }^{6}$ Neste sentido, veja belissima passagem sobre a força normativa do Direito Constitucional Brasileiro, no voto do eminente autor e Juiz Almeida Melo, in RJTAMG 69, p. 369, em caso de empréstimo bancário envolvedo pessoa física e Banco, em que esta foi equiparada a consumidor ex vi Art. 29 do CDCpor sua vulnerabilidade, APC 246.629-5, j.11.11.97, em benefício de Emanuel C. M., Rel. Juiz Almeida Melo.

Revista da Faculdade de Direito da UFRGS, v. 19, Março/2001 te com a de muitos autores do primeiro mundo ${ }^{67} \mathrm{O}$ mestre de Heidelberg ensina: o instrumento reequilibrador (re-personalizante, diria eu) do atual Direito Contratual são os direitos humanos. ${ }^{68}$ Iremos reconstruir a abalada ciência do Direito Privado através da valorização dos direitos do homem, da Igualdade que está nessa idéia. ${ }^{69}$

Interessante observar que também Jayme procura na Constituição a resposta para as antinomias modernas e a complexidade de sisemas legais descodificados. ${ }^{70}$ Historiadores do direito, como Bartolomé Clavero na Espanha, afirmam que para uma nova codificação ${ }^{71}$ é necessário uma crise social, mesmo uma revolução, a qual imponha uma nova Constituição, uma lista nova de direitos fundamentais. Da crise nascerá a resposta. No caso concreto, essa lista de direitos está na nossa Constituição Fede-

67 Veja $A R N A U D$, Andréjean, O Juiz e o auxiliar judiciário na aurora do pós-modernismo, in Revista AJURIS vol. 53 (1991), p. 223 e seg. . Em seu recente livro, ARNAUD, André-Jean, O modernidade e globalização, ed. Renovar, Rio de Janeiro, 1999, p. 201 e 202. Veja nos Estados Unidos, partindo de idéias economicistas a análise de MINDA, Garry, Postmodern Legal Movements- Law and Jurisprudence at Century's end, New York University Press, New York, 1995 e, na Alemanha, KAUFMANN, Arthur, Grundprobleme der Rechstphilosophie, München, Beck, 1994, p. 224 e seg.

as Veja JAYME, Curso, p. 247 e seg.

Sobre as dificuldades para efetivar e concretizar os direitos econômicos, sociais e culturais, veja CAMARGO, Ricardo Antônio Lucas, Os direitos econômicos, sociais e culturais no incício da década de noventa, in Revista Jurídica Mimeira, vol. 104, nov/dez. 1993, p. 24 e seg.

Jayme, Curso, p. 36 e seg.

${ }_{71}$ Assim a definição de Nolde: "La Codification pourrait être définie comme la création de „système" de régles de droit logiquement unifiées", citado por Erik Jayme, "Considerations historiques et actuelles sur la codification du Droit International Privé ', in Recueil des Cours de l'Académie de la Haye, n. 177 (1982, IV), p. 23. Pela sobrevivência da idéia de codificacão no Brasil, veja Andrade F́́bio Siebeneichler de Da CodificacãoCrônica de um Conceito, Ed.Livraria dos Advogados, Porto Alegre, 1997, p. 172.

72 Clavero, Bartolomé, Codificación y Constitución: Paradigmas de un binomio, in Quaderni Fiorentini, $N_{r} .18$ (1989), p. 81 e 82 .

3 A expressão constitui o título da famosa obra de 1979 do italiano Natalino Irti L'età della decodificarione ma exprevaria na qual previa o fim das codificaçoses que marcaram os sécs. XVIII eXXX. Os códigos superados pelas leis esparsas passarian a fonte resichal do direilo privado. Apesar de realista a "bservacao, contra ela levantaramse autorizadas vozes, no XI Congresso da „Acadén que legislar em forma de Código trazia em si muitas vantagens.

Defendendo uma codificação diferenciada, souple e especializada em tempos neo-liberais, Nusdeo, Fábio, Fundamentos para uma Codificação do Direito Econômico, Ed. Revista dos Tribunais, 1995, p. 169 e seg. Segundo Filomeno, p. 19, o CDC é um microsistema jurídico de caráter inter e multidisciplinar, Filomeno, José Geraldo Brito, Código Brasileiro de Defesa do Consumidor comentado pelos autores do Anteprojeto,
Ed. Foresnse Universitária, Rio de Janeiro, 6.ed., 1999, p. 19. foi ordenamento jurídico interno. ${ }^{72}$ É o que parece ter acontecido no Brasil, onde a Constitui-
ção de 1988 prima pela lista de direitos fundapentais, dentre os quais se destaca o definido pelo inciso XXXII do art. 5: "O Estado promo-
verá na forma da lei a defesa do consumidor." O art. 48 das Disposições Transitórias da Constituição Federal de 1988 ordenou ao legislador Consumidor, em plena era da descodificação. ${ }^{73}$

Assim, desta lista de direitos fundamennovos códigos, uma codificação já diferente..$^{74}$ novos códigos, uma codificação já diferente. ${ }^{74}$ a reconstrução através de nova micro-
Éna codificação ${ }^{75} \mathrm{O}$ Código de Defesa do Consu-

Revista da Faculdade de Direito da UFRGS, v. 19, Março/2001 ral de 1988 . Depois da crise da ditadura militar
, veio a "revolução" democrática e a lista de 
midor, Lei 8.078/90, nasce, pois, da Constituição brasileira. $\mathrm{O}$ artigo $5^{\circ}$ estabelece como direito fundamental do cidadão brasileiro, a defe sa dos seus direitos como consumidor. $\mathrm{O}$ artigo 170 estabelece que a ordem constitucional econômica do nosso mercado será baseada na livre iniciativa (caput), mas limitada pelos direito do consumidor (inciso V). E por fim, o artigo 48 das disposições transitórias, determina elaborar lei tutelar exatamente em forma de código: um todo construído, conjunto de normas siste matizado por uma idéia básica, a da proteção deste sujeito especial. $O$ instrumento de renovação teórica, o instrumento de renovação do direitos fundamentais do cidadão, estava dada estava posto na Constituição.

Em outras palavras, em tempos pós-modernos este sujeito identificado pelo Direito reivindicará suạ própria lei, leis especial subjetiva lei geral para todas as relações que atua como consumidor. Esta lei protetiva é uma micro-lei, lei privilegiadora, microsistema que acaba por abalar ou pelo menos modificar o sistema geral a que pertencia o sujeito, no caso, o Direito Civil. Trata-se, porém, de uma necessária concretização do Princípio da Igualdade, de tratamento desigual aos desiguais, da procura de uma igualdade material e momentânea para um sujeito com direitos diferentes, sujeito vulnerá-

vel, mais fraco. ${ }^{76} \mathrm{~A}$ lei especial e os direitos a ele assegurados são aqui instrumentos de Igualdade. ${ }^{77}$

Podemos, pois, comprovar a hi pótese de que a identificação constitucional deste sujeito $^{78}$ importou na declaração de seus direitos, que por sua vez levou à micro-codificação tutelar. Cabe agora examinar se o aparecimento deste sujeito, com sua lei especial tutelar, realmente teve o condão de abalar a teoria contratual existente e de rejuvenescer os ramos do direito em que há a presença deste sujeito de direitos novo. Isto é, tentaremos estudar o consumidor como sujeito de reconstrução ou como nas palavras belissimas do desembargador Antônio Janyr Dall'Agnol, um sujeito de "oxigenação", de reconstrução do Direito Civil como um todo.

2. Sujeito qualificado por direitos fundamentais e o Princípio da Igualdade

Em suas aulas na Faculdade de Direito da Universidade Federal do Rio Grande do Sul, explicitou o Prof. Erik Jayme que este sujeito de direitos pós-moderno é um sujeito qualificado, identificado com direitos constitucionais fundamentais, ${ }^{79}$ direitos humanos básicos ${ }^{80} \mathrm{e}$

${ }^{76}$ Veja Alexy, p. 357 e seg., sobre o direito de igualdade e o mandamento de tratamento desigual dos desiguais, p. 371 e seg.

7 Veja Alexy, p. 410 e seg., sobre o direito à uma ação positiva (e protetiva) do Estado.

7 Veja Alexy, p. 177 e seg., sobre direitos fundamentais como direitos subjetivos.

o Sobre as dificuldades para efetivar e concretizar os direitos econômicos, sociais e culturais, veja Camargo, Ricardo Antônio Lucas, Os direitos econômicos, sociais e culturais no incício da década de noventa, in Revista Jurídica Mimeira, vol. 104 , nov/dez. 1993, p. 24 e seg.

\$ A teoria de Jayme é baseada nos direitos humanos, pois foi concebida para o direito intemacional privado, a sua "nacionalizaçâo" teria como correspondente os direitos fundamentais, no caso brasileiro aqueles recebidos pela CF/88, a qual, porém, apresenta (à semelhança do art. 7 do CDC) uma interface aberta para os demais direitos humanos reconhecidos em Tratados Internacionais que o Brasil seja parte (Art $5 \$ 2$ da CFB8).

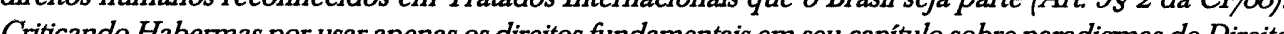
Criticando Habermas por usar apenas os direitos fundamentais em seu capitulo sobre paradigmas do Direito ent estato di Habermas" in Rivista Internazionale de Filosofia del Diritto, IV série, v. LXXI, n.1, 1994, p. 285.

Revista da Faculdade de Direito da UFRGS, v. 19, Março/2001 que, por isso, mesmo é o sujeito novo a ser protegido, tutelado pelo Direito. ${ }^{81}$ Para Erik Jayme o Leitmotive, isto é, o fio condutor do direito na pós-modernidade, do direito do século XXI serão os direitos humanos. ${ }^{82}$ Uma afirmação bastante forte no momento em que são justamente esses direitos humanos menosprezados em tantas guerras, violências, barbarismo, tanto individualismo, tanto egocentrismo realmente na nossa sociedade. Por vezes, parecemos uma sociedade darwiniana, onde somente os fortes sobreviverão, deixando os outros pelo caminho. Na teoria de Jayme, o revival dos direitos humanos é proposto como elemento guia, como novos e únicos valores seguros a utilizar neste caos legislativo e desregulador, de codificações e microssistemas, de leis especiais privilegiadoras e de leis gerais ultrapassadas; de soft law e da procura de uma equidade cada vez mais discursiva do que real. Os direitos fundamentais seriam as novas "normas fundamentais" ${ }^{\prime \prime 3}$ e estes direitos constitucionais influenciariam o novo direito privado, a ponto do direito civil assumir um novo papel social, como limi-

Esta foi a idéia básica de seu curso "Direito Patrimonial de Família na pós-modenridade", em 1996, ainda inédito. Veja, defendendo conclusōes similares, seu Curso de Haia,Jayme, Curso, p. 49 e seg.

Jayme, Curso, p. 37.

83 Assim Lorenzelti, Ricardo Luis, Fundamentos do Direito Privado, Ed. Revista dos Tribunais, 1998, p. 249 e seg.

${ }_{84}$ Assim Lorenzelti, Ricardo Luis, Fundamentos do Direito Privado, Ed. Revista dos Tribunais, 1998, p. 249 e seg. vol. 53 (1991), p. 223 e seg. . Em seu recente livro, Arnaud, André-Jean, O direito entre modernidade e globalização, ed. Renovar, Rio de Janeiro, 1999, p. 201 e 202 resume esta superação destacando : “...minhas teses são as que seguem: $1^{9}$ ) que a pós-modernidade em direito se caracteriza por uma preocupação de superaçâo dialética do paradigma "moderno" fundado sobre um feixe de conceitos englobando abstração e axiomatzizacão do direito, subjetivismo, simplicidade e segurança das relações jurídicas, separação da sociedado civile do Estado universalismo eunidade da razão jurdic $2^{\circ}$ ) que a crise contemporanea do Estado, do direto e da jut ca bu pode direito e da justiça... bem poderia ter como causa um esgotamento das raízes de nossas instituviçóes...; $3^{\circ}$ ) que a globalização bem poderia, pelo mesnos em parte, coincidir intelectualmente com um pensamento jurídico pós-moderno...um direito pós-moderno...se caracterizaria por uma vontade depragmatismo e derelativismo, pela aceitação do descentramento do sujeito, por umapluralidade das racionalidades, pelorisco que lhe é inerente, peloretorno da sociedade civil e pela apreensão das relaçôes jurídicas nacomplexidade daslógicas bruscamente estilhaçadas." Veja nos Estados Unidos, partindo de idéias economicistas a análise de Minda Garry, Postmodern Legal Movements- Law and Jurisprudence at Century's end, New York University Press, New York, 1995 e Mercuro, Nicholas e Medema Steven, Economic and the Law- from Porner to postmodernim, Pinceton Univesity Press, Paiceton, 1997, na $A$ post-modernism, Princeton University Press, Princeton, 1997, na Alemanha, ZIMA, Peter, Moderne/
Postmoderne, UTB, Francke, Tübingen, 1997.

${ }_{85}$ Assim ensina acriticamente Mercuro/Medema, p. 115 a 117.

e, como protetor do indivíduo e como inibidor de abusos. A teoria elaborada por Jayme é coincidente com a de muitos autores do primeiro rumento reequilibrador (re-personalizante, diria través da valorização dos direitos do homem

Realmente identificar no outro um sujeinhecer que o outro é totalmente pessoa, tem os tos não podem sobressair, abafar, diminuir, impedir o exercício e a efetividade dos direitos do doutrinadores da Law and Economics, assegudireitos a um agente é limitar o exercício reitos e das escolhas possiveis do utro...tem custos e externalidades. ${ }^{85}$ Aqui asseguram-se direitos humanos de proteção a um.

Revista da Faculdade de Direito da UFRGS, v. 19, Março/2001 

mos hoje com a possibilidade que seja um sistede verdadeiros legitimadores...se coisas que es- antinomias e da complexidade das relações atuais está na interpretação guiada e hierarquizad pelos direitos humanos. ${ }^{86} \mathrm{Se}$ os direitos humanos recebidos nas Constituições são direitos fundamentais, serão esses direitos fundamentais (normas constitucionais pétreas e básicas) que permitirão a interpretação do direito do novo mile nio, que terá justamente (e necessariamente) base constitucional. ${ }^{87}$

Este revivaldos direitos humanos, e no países do direito civil constitucional, tem um explicação simples. O direito civil perdeu em importância científica. Se nós na pósmodernidade já não acreditamos na ciência em geral, nem na ciência do direito, nem mesmo que o direito positivado do ti po germânicoromano seria um sistema fechado, se trabalhama aberto, aberto a fatores antes externos como a ideologia e a economia para que lhe sirvam tavam fora do Direito, que não eram juridicamente relevantes, passam a ser juridicament relevantes. ${ }^{88} \mathrm{Bem}$, neste sistema de vazio dogmático e científico, de incertezas e probab lidades, será justamente através da interpretação

constitucional dos direitos humanos, reconhecidos nas constituições dos países, que encontraremos nós a linha para reconstruir o Direito. ${ }^{89}$ A igualdade é uma das grandes meta-narrativa da modernidade ${ }^{90}$, mas a pós-modernidade tende a destacar o que há de "diferente" e "privilegiador" nestes novos direitos humanos ${ }^{91}$, permitindo a desigualdade formal para atingir a igualdade material. ${ }^{92}$ No caso do $\mathrm{CDC}$, asseguram-se direitos ao consumidor para alcançar a igualdade material dos desiguais, garantem-se direitos de escolha, reflexão, informação e transparência para proteger sua abalada liberdade ou autonomia de vontade dos consumidores nos contratos. Difícil dizer se esta seria uma qualidade pós-moderna, pois a autonomia da vontade domina tanto o direito moderno quanto pósmoderno.

Segundo Brilmayer ${ }^{93}$ tanto a modernidade, quanto a pós-modernidade são baseadas no discurso dos direitos, a primeira no discurso dos direitos adquiridos, na segurança (institucional), a segunda, nos direitos qualificados por sua origem, no discurso dos direitos fundamentais como resultados de um objetivo de política legislativa (narrativa), de um interesse

*Veja Jayme, Curso, p. 247 e seg.

$\&$ Assim também conclui Lorenzetti, Ricardo, Eljuez y las sentencias dificiles-Colision de Derechos, principios $y$ valores, in La Ley, 25.02.1998, p. 1 e seg.

* Trilhando outros caminhos, assim conclui Menezes Cordeiro, António, "Ciência do Direito e Metodologia Jurídica", in Revista da Ordem dos Advogados, 48, Dez. 1988, p. 75, ao concluir que o sistema presente do direito é "aberto, móvel, heterogéneo e cibernético."

* Veja Rizzatto Nunes, Luiz Antonio, Comentários ao CDC, Saraiva, São Paulo, 2000, p. 2 a 69, que examina o CDC a partir dos direitos fundamentais presentes na CF 88 .

* Defendendo que a isonomia de tratamento é uma das conquistas da modernidade, manifesta-se Lima, Paulo Roberto de Oliveira, Isonomia entre os sexos no sistema jurídico nacional, Ed. Revista dos Tribunais, São Paulo, 1993, p. 14.

9t Assim Brilmayer, Lea, Post-modernism in American Choice of Law, in Liber Memorialis François Laurent, Bruxel, 1989, p. 702 e 705

92 Também a modernidade permite a desigualdade formal para atingir a igualdade material, a pergunta é de grau, de qualificação, de tonalidades mais seguras (moderno) ou mais caóticas, inseguras, desreferenciadas (pós-moderno)

${ }^{93}$ Assim Brilmayer, p. 702 e 705.

Revista da Faculdade de Direito da UFRGS, v. 19, Março/2001 ou de um discurso social. Neste sentido, o sistema do CDC coaduna-se mais com a pósmodernidade, à procura da efetivação dos direitos humanos... direitos do consumidor no mercado atual. Certo é que o direito à igualdade é um dos primados do direito moderno, mas dade (Abwehrrechte direitos de defesa, direitos a uma conduta negativa - Rechte auf negative Handlungen $).{ }^{94}$ Pós-moderno é o direito a ser (e continuar) diferente ${ }^{95}$ (droit à la difference), ${ }^{96}$ é o direito à igualdade material (e tópica) reconstruída por ações positivas (Rechte auf positive Handlugen $)^{97}$ do Estado em pró do indivíduo identificado com determinado grupo. ${ }^{96}$

Assim, podemos concluir que a análise de Jayme traz duas contribuições importantes: 1) fornecer base científica para a concentração hoje existente no sujeito de direito consumidor, como o mais vulnerável no mercado de consumo. É aquele sujeito a merecer especial proteção do direito, princi palmente no que se refere ao exercício de seus direitos e em caso de conflito eventual de interesse com outros agentes (fornecedores etc.); 2) destacar a hierarquia dos direitos ora em conflito, no caso, direitos humanos, direitos fundamentais do consumidor, a exigir maior cuidado do aplicador da lei. A exigir capacidade para dar efeito útil para este mandamento constitucional, realizando um verda-

deiro diálogo de fontes. Em outras palavras, aplicar a lei infraconstitucional sobre os direitos do consumidor, o CDC, não pode mais ser um exercício programático, deve ser um exercício efetivo de concretização destes direitos no mundo dos fatos, uma vez que esta lei envolve direitos e garantias constitucionais dos mais fracos na sociedade e deve realizar sua finalidade legislativa de proteção efetiva. $\mathrm{O} C D C$ não é um discurso pós-moderno, é um instrumento.

Mister, pois, analisar o CDC como sistema como contexto construído, codificado, organizado de -identificação do sujeito beneficiado. Isto porque o CDC brasileiro não é um Código de "consumo", como a consolidação legal francesa denominada Code de la Consommation, nem é uma lei geral sobre contratos de adesão comerciais e civis, concentrada no método do uso das cláusulas contratuais gerais, como lei alemã de 1976, AGBGesetz. $^{99} \mathrm{O}$ CDC brasileiro concentra-se justamente no sujeito de direitos, visa proteger este sujeito, sistematiza suas normas a partir desta idéia básica de proteção de apenas um sujeito "diferente" da sociedade de consumo: o consumidor. É Código (todo construído sistemático) de Proteção (idéia básica instrumental e organizadora do sistema de normas oriundas de várias disciplinas necessárias ao reequilibrio e efetivação desta defesa e tutela especial) do Consumidor! são em sua maioria direitos "negativos" de igual-

Veja as lições de Alexy, p. 174.

95 O retorno ao sentimento busca resgatar um conceito de 'felicidade individual' em todas as searas jurídicas, especialmente em matéria de Direito de Família. Como bem destaca Carlos Alberto Ghersi, "es necesario antes de desarollar estos derechos derivados, marcar o insistir en algo previo: el concepto posmodernista de antes de desarollar estos derechos derivados, marcar o insistir en algo previo: el concepto posmodernista de
la felicidad, pues condiciona y explicita toda esta temática de recreación de derechos individuales desde el la felicidad, pues condiciona y explicita toda esta temática de recreación de derechos individuales desde el
derecho personalisimo. (...) Esto comienza a ser la base de la nueva felicidad, el placer y el vivir sin culpa. Se presenta como algo realista, que corregía utopías, se exaltaba la calidad de vida, por sobre la vida" (in La posmodernidad jurídica, Ed. Gowa, 1995, p. 33).

${ }^{\circ}$ Jayme, Cours, p. 251.

or Veja sobr estes direitos subjetivos, Alexy, p. 179

- Veja Sarlet, Ingo W., A eficácia dos direitos fundamentais, Livraria dos Advogados, Porto Alegre, 1998, p. 48.

o Sobre Direito Comparado, veja Nery, Nelson Jr., Código Brasileiro de Defesa do Consumidor comentado pelos autores do Anteprojeto) Ed. Foresnse Universitária, Rio de Janeiro, 6.ed., 1999, p. 429 e seg. 
Eis porque identificar este sujeito protegido, sujeito de direitos especiais, agente escolhido para receber um microsistema tutelar legal é a pedra de toque do CDC. Os direitos básicos positivados são "do consumidor", assim definido pelo CDC e de ninguém mais. Dai hoje as constantes discussões judiciais de agentes econômicos, especialmente pessoas jurídicas comerciantes querendo ser identificadas como consumidores. Esta "vontade" de ser identificado como consumidor apenas comprova que o regime imposto no $\mathrm{CDC}$ é um regime de exceência, funcional e funcionando com certo sucesso no direito brasileiro.

O aplicador da lei tutelar deve relembrare, porém, que os direitos básicos do CDC foram assegurados somente aos consumidores, motivo pelo qual todos querem esta "posição", este papel, este status, único que assegura a subjetivação destes direitos, a entrada destes "interesses" $/$ 'expectativas" em seu patrimônio, que assegura $o$ acesso aqueles instrumentos efetivos e práticos de proteção e realização dos direitos impostos e criados pelo CDC. Hoje todos querem ser consumidores do CDC. Este, porém, não é o sistema do CDC, que visa proteger só ao "consumidor", aquele que ele mesmo define de forma estrita (Art.2 do CDC) ou aqueles que ele equipara a consumidor (Art. 2, §único, Art. 17 e Art. 29 do CDC), sempre com base em sua norma objetivo ${ }^{100}$ do Art. 4,inciso I do CDC: a proteção do vulnerável.

Em resumo, o direito do consumidor é direito não só de origem constitucional, mas sim direito fundamental, direito humano de nova geração, positivado no Art. $5^{\circ} \mathrm{XXXII}$ da $\mathrm{CF} /$ 88. Trata-se de um direito positivo de atuação do Estado na sua proteção. É privilégio, projeção do espírito humano, para todos os cidadãos, brasileiros e estrangeiros aqui residentes.

Para as pessoas físicas não é apenas princípio da ordem econômica ou direito econômco e social ${ }^{101}$ é direito fundamental ! Pareceme, pois, que o intérprete deve considerar este mandamento constitucional e sua dupla hierarquia: para as pessoas físicas, o direito do consumidor é direito fundamental, sendo que o cidadão pode exigir proteção do Estado para os seus novos direitos subjetivos tutelares. ${ }^{102}$ Tratase de um privilégio, uma garantia, uma liberdade de origem constitucional, um direito fundamental básico. Para todos os demais agentes econômicos, especialmente para as pessoa jurídicas, o direito do consumidor é apenas um sistema limitador da livre iniciativa do caput do Art. 170 da $\mathrm{CF} / 88$, sistema orientador da ordem econômica constitucional brasileira. Dai, correto o CDC, que em seu artigo primeiro esclarece que este "código", este sistema de normas construído e organizado a partir da identificação do sujeito beneficiado, "estabelece normas de proteção do consumidor, de ordem pública $e$ interesse social".

Ito Veja sobre normas-objetivo em geral, Grau, Eros Roberto," Interpretando o Código de Defesa do Consumidor algumas notas", in Direito do Consumidor 5, p. $183 \mathrm{e} \mathrm{seg.}$

IoI Veja CAMARGO, p.24 e seg.

${ }^{102}$ Veja, neste sentido, decisão de lider da $5^{\underline{a}}$ Câmara Civel do TAMG concedendo a desconsideração da personalidade da pessoa jurídica com base no Art. 28 do CDC, justamente em beneficio de consumidores pessoas fisicas lesadas por um fornecedor. (5 $5^{a}$ Câmara Cível, Ap. Civ. 114.409-4, rel. Juiz Aloysio Nogueira, j. 12.03.92, publicado in Revista Jurídica Mineira, vol. 102, julho/agosto de 1993, p.108-120). Em belíssimo j. 12.03 .92 , publicado in Revista Juridica Mineira, vol. 102, julho/agosto de 1993, p.108-120). Em belissimo
e erudito voto vencedor, esteleading case supera (do italiano, superamento) os dogmas comercialistas para e erudito voto vencedor, esteleading case supera (do italiano, superamento) os dogmas comercialts

Revista da Faculdade de Direito da UFRGS, v. 19, Março/2001
B. As várias definições de consumidor no $\mathrm{CDC}$ e pluralismo de sujeitos

1. A definição de consumidor destinatá rio final: por uma interpretação finalista e superadora da proteção apenas do contratante

$\mathrm{O}$ CDC define consumidor stricto sensu no Art. $2^{\circ}$ como "toda aquela pessoa fisica ou jurídica que adquire ou utiliza produto ou serviço como destinatária final." Tive a oportunidade de afirmar que esta definição é bastante objetiva, mas que sua interpretação pode e deve ser finalistica. ${ }^{103}$ Parece-me uma boa oportunidade tecer algumas considerações em defesa desta interpretação finalista do conceito indeterminado "destinatário final" do Art. $2^{\underline{0}}$ do CDC.

a. Necessária utilização conjunta dos métodos de interpretação

Interpretar é estabelecer o sentido e o alcance da norma ("ação cujo evento útil é entender"). ${ }^{104}$ Subsumir o caso à lei e interpreta esta são atividades normais do aplicador da lei, ${ }^{10.5}$ sempre submetidas aos métodos de interpretação clássicos: interpretação gramatical, lógicosistemática e teleológica. ${ }^{106}$ Eis porque me sinto muito a vontade para defender uma interpretação finalística, sistemática e teleológica do Art $2^{\circ}$ do CDC, que denomino em minha obra de interpretação "finalista" da definição de consumidor stricto sens

${ }_{103}$ Veja nosso livro, Contratos, p. 141.

lot MIRANDA, Custódio da Piedade Ubaldino, Interpretação e Integração dos Negócios Jurídicos, Ed. Revista dos Tribunais, São Paulo, 1989, p. 88 (citando Emílio Betti)

${ }^{105}$ MIRANDA, op. cit, p 109

${ }^{106}$ Assim, incluindo a interpretação histórica e evolutiva, REALE, Miguel, Lições preliminares de Direito, Ed. Saraiva, 16.ed., São Paulo, 1988, p. 277 e seg., e também MIRANDA, op. cit, p. 121 e seg.
Tendo em vista a importância desta definição principal de consumidor do Art. $2^{\underline{\underline{o}}}$ do CDC, parece-me que o conceito indeterminado "destinatário final" não comporta apenas interpretação literal como querem os maximalistas, bastando a destinação final fática da prestação de serviços, por exemplo a prestação securitária, de assunção/transferência de riscos e de pagamento da indenização pelo valor do seguro. Esta interpretação simplista é inadaptada em caso de serviços, cuja prestação é imaterial e sempre "final" por essência. Por esta interpretação apenas gramatical,por exemplo, todo contrato de seguro, nacional ou internacional, profissional ou que não fosse regulado pelo $\mathrm{CDc}$, a deixar sem finalidade o direito comercial de seguros, por exemplo, seguros marítimos, seguros dos contratos internacionais, etc. Repito, face a importância do Art. $2^{\circ}$ do CDC, mister utilizar simultaneamente os outros critérios normais de infinal é retirar o bem de mercado (ato objetivo), mas e se o sujeito adquire o bem para utilizá-lo em sua profissão, adquire como profissional (elemento subjetivo), com fim de lucro, também deve ser considerado "destinatário final"? Se a definição do Art. $2^{\circ}$ do CDC sozinha não responde à pergunta, é necessário interpretar a expressão "destinatário final" conforme os métodos antes mencionados.

Em outras palavras, este conceito indeterminado ou expressão legal "destinação final" merece também interpretação na lógica no sistema do CDC, que é micro sistema terpretação das leis. Certamente, ser destinatário 
protetivo, de origem constitucional, sistema tutelar apenas do consumidor. Consumidor "destinatário final" do serviço securitário é neste sistema tanto o consumidor-contratante, como o consumidor-beneficário do seguro. Interpretação sistemática esta que deve cumprir - ou considerar - (sempre) os princípios impostos pelo Art. 4 do CDC, especialmente, o princípio da vulnerabilidade de seu inciso I. O sistema do CDC construiu-se com esta idéia base de proteção do vulnerável, de tratamento protetivo e desigual do desigual, do mais fraco na sociedade de consumo; logo, a expressão "destinação final" contém a idéia base de seu sistema: reigualdade e re-equilíbrio (Art. 4,III do CDC). Por fim, para realizar a Justiça no caso concreto, o Art. $2^{\circ}$ do CDC deve ser interpretado conforme a sua ratio legis, sua finalidade atual, como ensina o método de interpretação teleológica defendido pelo grande jurista Jhering. ${ }^{107}$ A ratio legis de todas as normas do CDC está positivada, narrada, esclarecida no art. $4^{\circ}$ do $C D C,{ }^{108}$ que impõe respeito, lealdade, transparência e harmonia nas relações de consumo, atendido o princípio do reconhecimento da vulnerabilidade do consumidor, da boa-fé e equilíbrio nas relações entre consumidores e fornecedores.

Ao interpretar o Art. $2^{\circ}$ do CDC, segundo este métodos simultaneamente, parece-me não bastar mais a "destinação final" fática do produto ou serviço. Se bastasse todos os contratos que envolvessem dinheiro, como os contratos bancários, financeiros e securitários submeter-se-iam sempre ao $\mathrm{CDC}$, uma vez que faticamente alguém (contratante ou terceiro)

recebe, em algum momento, uma quantia. Assim também, em todos os serviços absolutamen te imateriais (fazeres economicamente relevantes, como informações), seria dificil identifica um consumidor, destinatário final fático. Mister interpretar "destinatário final" como destinatário final econômico e fático, permitindo assim uma melhor identificação deste sujeito a proteger na complexidade e imaterialidade das relações contratuais atuais.

Segundo ensina um dos autores do CDC, José Geraldo Brito Filomeno, o conceito de adotado pelo Art. $2^{\circ}$ é "exclusivamente de caráter econômico, ou seja, levando-se em consideração tão-somente o personagem que no mercado de consumo adquire bens ou então contrata a prestação de serviços, como destinatário final, pressupondo-se que assim age com vistas ao atendimento de uma necessidade pró pria e não para o desenvolvimento de uma outra atividade negocial." 109 Este abalizado autor conclui que no CDC: "entendemos por consumidor, qualquer pessoa fisica ou jurídica que, iso ladamente ou coletivamente, contrate para consumo final, em beneficio próprio ou de outrem, a aquisição ou a locação de bens, bem como a prestação de um serviço." 110

Eis porque, como declarada "finalista", considero que a definição de consumidor do Art. $2^{\circ}$ do CDC deve ser interpretada "restritivamente" dentro do sistema e da ratio legis de proteção dos vulneráveis. Trata-se do pilar que sustenta a tutela especial, agora concedida aos consumidores, e esta tutela só existe

${ }^{107}$ Veja Reale, op. cit., p.286.

${ }^{108}$ Segundo Eros Roberto Grau trata-se de "norma objetivo", norma guia do sistema, veja GRAU, Roberto, Interpretando o código de Defesa do Consumidor: algumas notas, in Revista Direito do Consumidor, vol. 5 p. 183 e seg.

${ }^{109}$ FLLOMENO, op. cit., pg. 26.

${ }^{110}$ FLLOMENO, op. cit.,p. 27.

III MARQUES, Contratos, p. 149

Revista da Faculdade de Direito da UFRGS, v. 19, Março/2001 porque o consumidor é a parte vulnerável nas relações contratuais no mercado, como afirm o próprio CDC no Art. $4 .^{\circ}$, inciso I. Logo, convém delimitar claramente quem merece esta tutela e quem não a necessita, quem é o consumidor e quem não é. Proponho, então, que se interprete a expressão "destinatário final" do Art. $2^{\circ}$ de maneira restrita, como destinatário final fático e econômico ${ }^{112}$, como requerem os principios básicos do CDC, expostos no Art. $4^{\circ}$ e $6^{\circ}$.

Parece-me que "destinatário final é aquele destinatário fático e econômico do bem ou se viço, seja ele pessoa jurídica ou física. Logo segundo esta interpretação teleológica não basta ser destinatário fático do produto, retirá-lo da cadeia de produção, levá-lo para o escritório ou residência, é necessário ser destinatário fina econômico do bem, não adquiri-lo para reven$\mathrm{da}$, não adquiri-lo para uso profissional, pois o

bem seria novamente um instrumento de produção cujo preço será incluído no preço final do profissional que o adquiriu.

O destinatário final é o Endver braucher, o consumidor final, o que retira o bem do mercado ao adquirir ou simples mente utilizá-lo (destinatário final fático), aquele que coloca um fim na cadeia de produção (destinatário final econômico) e não aquele que utiliza o bem para continuar a produzir, pois ele não é o consumidor final, ele está transformando o bem, utilizando o bem, ${ }^{113}$ incluindo o serviço contratado no seu, para oferecê-lo por sua vez ao seu cliente, seu consumidor, utilizandoo no seu serviço de construção, no seus cálculos do preço da licitação, como insumo da sua produção. ${ }^{114}$ Neste sentido já decidiu a jurisprudência brasileira, ${ }^{115}$ excluin-

${ }^{112}$ Contra esta posição, considerando que "nâo cabe ao intérprete distinguir onde o legislador nāo distinguiu"...porque "subverter-se-ia a estrutura do sistema, transformando-se o aplicador da lei em legislador, o que não pode ser infenso à críticas", ROBERTO SENISE LISBOA, Contratos Difusos e Coletivos, Ed. RT, São Paulo, 1997, p. 300 e 301.

${ }^{113}$ Assim decisão da 4" Câmara Cível, AI 172.292-9, Rel. Juiz Jarbas Ladeira, j. 23.05.1994, que em nenhum momento considerou o comerciante, que alugava o espaco em shopping center como parte necesśria da su profissâo, como consumidor. Publicado na integra in Revista Jurídica Mineira vol 115, setembrofa da sua de 1995, p.162-165. A ementa é a seguinte: "LOCACÁO COMERCIAL - SHOPPING CENTER de 1995, p.162-165. A ementa é a seguinte.' 'LOCACCAO COMERCLAL - SHOPPING CENTER ALUGUEL - TEORIA DA IMPREVISAO - REVISIONAL. Em face das peculiaridades da locação em shopping center, cujo aluguel é fixado em porcentagem sobre o faturamento das empresas, com estipulação minima, a redução acentuada do movimento comercial da locataria, em decorrência da crise econômica, implica fato imprevisível que modifica o equilíbrio existente entre as partes, hipótese em que o reajuste excessivo de aluguéis configura periculum in mora, a justificar a concessão de liminar para fixaçâo provisóri 14 MARQUES, Contratos, p. 146.

${ }^{115}$ CONTRATO DE FINANCIAMENTO-PESSOA JURÍDICA- FINANCIAMENTO DESTINADO AO INCREMENTO DAS ATIVIDADES DA EMPRESA - INEXISTENCIA DE PROVA DA VULNERABILIDADE E DO DESEQUILÍBRIO CONTRATUAL - RELAČ̃O DE CONSUMO NÃO CARACTERIZADA - INAPLICABILIDADE DE LEGISLAČ̃̃O CONSUMERISTA. A pessoa juŕdica que tome recursos no mercado financeiro para incrementar atividade econômica não caracteriza destinatár final, que o CDC quer proteger, qual seja o efetivo destinatário final, ou seja o destinatário econômico não mais do servico banćrio, mais do sevco as pulnerabilidade perante o banco agravado, dentre

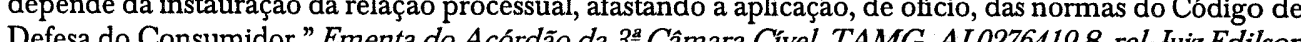
Defesa do Consumidor." Ementa do Acórdão da $3^{a}$ Câmara Cível, TAMG, AI 0276419-8, rel. Juiz Edilson
Fernandes, j. 28.04.1999, decisão unânime. Fonte www.ta.mg.gov.br/consulta Acordão 22971 
do contratantes bancários com finalidade de repasse (aquisição de bens de capital) da definição de consumidor stricto sensu. ${ }^{116}$

b. Importância do princípio da vulnerabilidade

Daí a importância do elemento vulnerabilidade na interpretação finalista do Art. $2^{2}$ do CDC. Com base no princípio da vulnerabilidade do consumidor, disposto no Art. $4 .^{\circ}$, inc. I do CDC, identificamos em nossa obra três tipos de vulnerabilidade: 1 . a vulnerabilidade técnica (falta de conhecimentos específicos e técnicos sobre o objeto que está adquirindo o serviço necessário, suas características, sua utilidade, seus riscos ), 2. a vulnerabilidade jurídica (como é o caso do consumidor pessoa física leiga ou do profissional liberal frente a uma instituição bancária ou financeira) e 3. a vulnerabilidade fática (neste caso, o ponto de a posição monopolista de fato ou de direito, a especialidade ou a redução da oferta, o seu grande poder econômico). ${ }^{117}$

Em se tratando de pessoa física, milita ex vi lege uma presunção de sua vulneraconcentração é o possível parceiro contratual,

bilidade, vulnerabilidade esta que é bastante importante em se tratando de contratos bancários com pessoas fisicas e que leva a aplicação do $\mathrm{CDC}$ aos contratos bancários em geral, concluídos com pessoas físicas, até prova em contrário. O mesmo se pode afirmar em se tratando de contratos de seguros concluídos ou beneficiando consumidores-pessoas fisicas. ${ }^{18}$ Aceita esta presunção, esta inverte a lógica da prova da destinação final a favor do consumidor pessoa fisica, protegendo mais eficazmente o vulnerável nestas relações desequilibradas. A pessoa jurídica, ainda mais quando atua na sua área de atividade profissional, não se beneficia da presunção geral de vulnerabilidade do Art. 4,I do CDC (válida somente para pessoas fisicas), mas pode provar sua vulnerabilidade in concreto, sempre que destinatário final-econômico do produto ou serviço (Art. $2^{\circ}$ do CDC). ${ }^{119}$

Grande parte da doutrina concorda tam bém com estas ponderações, ${ }^{120}$ pois esta interpretação considera que consumidores stricto sensu são aqueles mais fracos, os leigos, os nãoempresários, ou como afirma o pioneiro do consumerismo no Brasil, Konder Comparato são aqueles "que não dispõem de controle sobre os bens de produção e, por conseguinte, de vem sesubmeter aopoder dostitulares destes." ${ }^{21}$

${ }^{116}$ APELAÇÃO...MÚTUO. PESSOA JURÍDICA. RELAÇÃO DE CONSUMO INOCORRENTE...3. Consumidor, nos termos da Lei 8.078 , de 1990 , é o destinatário final do produto ou serviço. 4. A pessoa jurídica que se dedica à atividade mercantil não é destinatária final de capital mutuado, pois este é meio para a execução da mencionada atividade. A aplicação da Lei 8.078, de 1990, resta afastada. Ementa de Acórdão da $2^{2}$ Câmara Cível, TAMG, APC 02880884, j. 1409999, Rel. Juiz Manuel Saramago. No mesmo sentido, Acórdão da $2^{\underline{z}}$ Câmara Cível, APC 02796094, j. 05.0499, Rel. Juiz Manuel Saramago. Decisōes unânimes. Fonte www.ta.mg.gov.br/consulta Acordão 26918 e 27290

III MARQUES, Contratos, p. 147 e 148.

${ }^{118}$ Assim nos manifestamos, MARQUES, Contratos, p. 155.

${ }^{119}$ Assim nos manifestamos, MARQUES, Contratos, p. 155.

200 Veja FLOMENO, José Geraldo Brito, in Código de Defesa do Consumidor-comentado pelos Autores do Anteprojeto, 5.Ed., Forense Universitária, Rio de Janeiro, 1998, p. 27 e seg.

${ }^{21}$ COMPARATO, Fábio Konder, A proteção ao consumidor : Importante Capítulo do Direito Econômico", in RDM, 15/16, 1974 apud FLOMENO, op. cit., p. 27.
A interpretação finalista aqui defendida restringe conscientemente a figura do consumidor àquele que adquire (utiliza) um produto para uso próprio e de sua família. Consumidor seria o não profissional, pois o fim do CDC tutelar de maneira especial um grupo da sociedade que é mais vulnerável. Considero que restringindo o campo de aplicação do CDC àqueles que necessitam de proteção, ficará assegurado um nível mais alto de proteção para estes, pois a jurisprudência será construída em casos, onde o consumidor era realmente a parte mais fraca da relação de consumo e não sobre casos em que profissionais-consumidores reclamam mais benesses do que o Direito Comercial já lhes concede. ${ }^{122} \mathrm{O}$ sistema do CDC foi construído para este fim, e sua origem constitucional deve ser a guia de sua interpretação: um direito do consumidor efetivo que concretize direitos fundamentais, direitos subjetivos para o mais fraco que mereceu receber esta tutela especial constitucional, o consumidor pessoa fisica. Nas relações inter-comerciantes, o direito do consumidor serve apenas de orientação da conduta profissional, limite à própria liberdade de iniciativa e autonomia privada.

Em dezembro de 1999, o Supremo Tri bunal Federal, no caso TEKA v. AIGLON. ${ }^{123}$ apoiou esta visão finalista do campo de aplicação do $\mathrm{CDc}$, em decisão que merece nossa atenção

Neste caso entre duas grandes empresas, a Tecelagem brasileira comprara algodão para fazer seus produtos e fora condenada a pagar certa quantia por laudo arbitral estrangeiro. No momento da homologação da sentença arbitra pelo STF, alegou a pessoa jurídica brasileira ser

${ }^{122}$ MARQUES, Contratos, p. 142.

${ }^{123}$ SENTENÇA ESTRANGEIRA CONTESTADA No 5.847-1, Acórdão promulgado em 01.12.1999, Rel. Min. Maurício Corrêa.

${ }^{124}$ Frase de fls. 253 do original. SENTENÇA ESTRANGEIRA CONTESTADA No 5.847-1, Acórdão promulgado em 01.12.1999, Min. Maurício Corrêa.

Revista da Faculdade de Direito da UFRGS, v. 19, Março/2001 "consumidora" do algodão e que, como tal, não teria o contrato seguido os cuidados necessários de destaque das cláusulas limitadoras de direitos do consumidor (Art. 54 do CDC), assim como os deveres de informação frente ao consumidor não teriam sido cumpridos (Art. 18, 30, 46, 54 do CDC), que tal cláusula de eleição do foro (no caso, do árbitro) seria nula, uma vez que não se aplicam a consumidores por força do Art. 51 VII do CDC (instância "compulsória").

Neste leading case, o STF deixou bem claro que os bens e serviços usados diretamente na produção de outros bens e serviços, estes sim destinados ao consumidor final, assim como comércio internacional de produção não está abrangido pelo $\mathrm{CDC}$ e que a destinação final exigida pelo Art. $2^{\circ}$ do $\mathrm{CDC}$ deve levar em conta as circunstâncias do caso:

"De igual forma, o laudo exarado pela Liverpool Cotton Association Ltd. nada tem a ver com o Código Nacional de Defesa do Consumidor, para escusar-se a devedora da obrigação assumida, por não se aplicar à empresa importadora de produto destinado ao consumidor final, conforme prevê $o$ art. 2 , que define o consumidor como toda "pessoa fisica ou jurídica que adquire ou utiliza produto ou serviço como destinatário final." 124

O Item 5 da referida ementa chega a afirmar, mais do que finalisticamente: "HOMOLOGAÇÃO DE LAUDO ARBITRAL ESTRANGEIRO... INAPLICAÇĀO DO CÓDIGO DE DEFESA DO CONSUMIDOR... 4. $O$ CODIGO DE PROTEÇAO E DEFESA DO

Revista da Faculdade de Direito da UFRGS, v. 19, Março/2001 
CONSUMIDOR, CONFORME DISPÕE SEU ARTIGO 2, APLICA-SE SOMENTE A PES SOA FÍSICA OUJURDICA QUE ADQUIRE OU UTILIZA PRODUTO OU SERVICO COMO DESTINATÁRIO FINAL"

Se a todos considerarmos "consumidores", a nenhum trataremos diferentemente, e o direito especial de proteção imposto pelo CDC passaria a ser um direito comum, que já não mais serve para reequilibrar o desequilibrado $\mathrm{e}$ proteger o não-igual. $\mathrm{E}$ mais, passa a ser um direito comum, nem civil, mas sim comercial, nacional e internacional, o que não nos parece correto. A definição do Art. $2^{\circ}$ é a regra basilar do $\mathrm{CDC}$ e deve seguir seu princípio e sua ratio legis. É esta mesma ratio que incluiu no CDC possibilidades de equi paração, de tratamento analógico e de expansão, mas não no princípio, sim na exceção. O direito é a arte de distinguir e a ratio legis do $\mathrm{CDC}$ não pode ser desconsiderada de forma a levar a própria destruição do que representa, logo, da própria ratio legis de proteção preferencial dos mais fracos, mais vulneráveis no mercado. Defendemos, pois, a necessária a conjunção de fatores finalísticos, destinação final fática e econômica do serviço, com base no Art. 4, I do CDC (ratio de vulnerabilidade).

c. A destinação final como superação do status de "contratante"

Note-se que, mesmo finalista, a interpre-

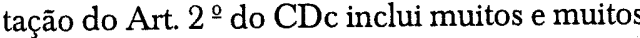

${ }^{225}$ Sobre a superação do status de terceiro, veja nosso artigo "Proposta", revista direito do Consumidor, vol. 33, p. 94 a 98. os Oexemplo mais interessante foi o das linhas telefônicas, onde antigamente o consumidor, para ter este servico, acabav acionista da empresa hoje, o consumidor é muitas vezes levado a ser "cooperativado" ou sócio de uma empresa só para consumidor ou ter lazer.

IJ A própria utilização da expressão "sujeito" (ator) no lugar da antiga denominacão indivíduo (quid) já indicia esta plumlidade Sobre fragmentação do sujeito, veja, citando Stuart Hall, Doll, Johannes, Avaliação na pós-modernidade, in Paiva Maria da Graça Gomes e Brugalli, Marlene (Org.), Avaliação- Novas Tendências -novos Paradigmas, Ed. Mercado Aberto, Porto Aleore, 2000, p. 33: "Na modernidade, o indivíduo-a tradução latina desta palavra significa "o que näo pode ser dividido"-é conceiturado como um ser interio e integrado que passui uma identidade própria um núcleo que naa pode ser dividido -e conceiúuado como um ser inteiro existencial não existe, o "indivíduo" pode ser dividido, fragmentado até o ponto em que um lado deste pode ser considerado motto, enquanto o outro continua vivo..."

Revista da Faculdade de Direito da UFRGS, v. 19, Março/200 I quece ou, na linguagem do CDC, é remunerado pelo serviço, mas a lei não exige que alguém empobreça a pagar diretamente este serviço (pobre, no sentido, que suporta a onerosidade do serviço). A remuneração pode ser indireta e por terceiro... ${ }^{128} \mathrm{O}$ serviço de consumo é que deve ser "remunerado", não se exige que o consumidor o tenha remunerado diretamente. Mesmo serviços gratuitos são regulados pelo CDC (Art. 39 regula as amostras grátis), pois remunerados indiretamente no negócio principal, na fidelidade dai oriunda e no marketing usado, enfim no preço final do serviço ou produto colocado no mercado por aquele fornecedor. Assim, se a sogra de um empregado de fábrica é a destinatária final de um serviço médico organizado por uma operadora de saúde é esta sogra consumidora, mesmo sè sequer o empregado "pagou" algo à organizadora da cadeia (a operadora do plano de saúde), mas esta teve seu serviço remunerado pela empresa (consumidora indireta), que por sua vez não cobrou do empregado, nem da sogra. $\mathrm{O}$ serviço de consumo é que é remunerado, não se exige a remuneração pelo consumidor direto (destinatário final), mas sim por alguém, consumidor indireto ou por seu representante, consumidor-equi parado.

B. A equiparação a consumidor: técnica adaptada à fragmentação do sujeito e à complexidade das relações de serviços

Quanto às definições de consumidor equi parado, são elas por excelência plurais e

excelencia plurais e

${ }_{128}^{28}$ Interessante observar que as leis da Argentina, Uruguai e Paraguai todas preferem a expressāo "onerosidade do serviço", dando a entender que deve haver umminus, pois na origem da palavra está o ônus ou "peso", uma "plus", no fato do fornecedor não fazer este serviço em ação benemérita, mas sim negocial, em lucrar ele (plus) direta ou indiretamente com este serviço, isto é, no fato de haver enriquecimento de um, mesmo sem empobrecimento do outro na prestação efetiva deste serviço principal ou acessório, simples ou complexo, empobrecimento do outro na prestaçáo efetiva deste serviço principal ou acess
que foi colocado no mercado de consumo brasileiro e usado por consumidores.

${ }^{220}$ BENJAMIN, Antonio Herman, Comentários ao Código de Proteção do Consumidor, Coord.Juarez Oliveira, Ed. Saraiva, São Paulo, 1991, p. 81

Revista da Faculdade de Direito da UFRGS, v. 19, Março/2001 uma das mais interessantes tentativas do CDC de adaptar-se à complexidade material das relamercado e à crescente pluralidade de sujeitos dos tempos pós-modernos. São consumidores equi parados $e x$ vi o parágrafo único do art. $2^{-}$ indetermináveis, que haja intervindo na relação de serviço, ex vi o Art. 17 do $\mathrm{CDC}$, todas as vítimas dos fatos do serviço, por exemplo, os pessoas determináveis ou não expostas às práticas comerciais de oferta, de contratos de adede bancos de dados, sempre que vulneráveis in concreto.

Superação da destinação final na equi paração

de Defesa do Consumidor, Antônio Herman Benjamin, em matéria de "equi paração" à consumidor o requisito da "destinação final" do produto ou serviço é irrelevante. ${ }^{129}$ Efetivamente, soas "intervenientes em relações de consumo" (§ único do Art. $2^{\circ}$ ), pessoas "vítimas" de fato do produto ou serviço (Art. 17) e pessoas "expostas às práticas nele previstas" (Art. 29) à "consumidor, o essencial não é o requisito da contrário, a lei tutelar equi para pessoas que não são necessariamente destinatários finais fáticos e são necessariamente destinatarios finais faticos e
econômico do serviço ou produto incluindo-as do serviço e ex vi o Art. 29 do CDC, todas as 
excepcionalmente, por sua característica de fraqueza ou vulnerabilidade, como "consumidor equiparado". ${ }^{13}$

Parte da doutrina, ${ }^{131}$ considera que o Art 29 do CDC protege apenas o consumidor "potencial". Protegeria apenas aqueles "destinatários finais" típicos do produto ou serviço, ma como estes ainda não teriam contrataram (potencialidade) mereceriam proteção "abstrata" contra abusos através do Art. 29 do CDC. Neste caso estariam incluídas, por exemplo, as pessoas que, após receberem mensagem publicitária dirigem-se a loja do servidor e este nega-se contratar. ${ }^{132}$ Parece-nos que o Art. 29 do CDC inclui também (e necessariamente) o "consumidor equiparado" concreto exposto à prática comercial (sujeição/fraqueza), logo, não concordamos com esta visão reducionista em excesso do Art. 29 do CDC. Como esclarece Antônio Herman Benjamin, em interpretação histórica: "o conceito do Art. 29 integrava, a princípio, o corpo do Art. $2^{\circ}$. Como conseqüência de lobby empresarial que queria eliminá-lo por completo, foi transportado, por sugestão minha, para $o$ Capítulo V...O conceito de consumidor é, en tão, não apenas aquele que 'adquire ou utiliza produto ou serviço' (Art. 2\%), mas igualmente as pessoas expostas às práticas previstas no Código (Art. 29). Vale dizer: pode ser visto concretamente (Art. $2^{\circ}$ ) ou abstratamente(Art. 29). (grifos do autor)..$^{133}$ ${ }^{130}$ Assim concorda Antonio Janyr DALL'AGNOL, Antonio Janyr, Direito do consumidor e serviços bancários
e financeiros - Aplicação do CDC nas atividades bancárias, in Revista Direito do Consumidor, vol. 27 (1998),,p. 13 .

${ }^{13 t}$ Especialmente COELHO, Fábio Ulhoa, Comentários ao Código de Proteção do Consumidor, Coord. Juarez Oliveira, Ed. Saraiva, São Paulo, 1991, p. 148. Veja-se também SIL VEIRA, Reynaldo Andrade da, Práticas Mercantis no Direito do Consumidor, Ed. Juruá, Curitiba, $p .80$.

${ }_{132}$ Veja-se caso "Mesbla" e parecer de TOMASETTI, Alcides J., Oferta contratual em mensagem publicitária, in Revista Direito do Consumidor, vol. 4 (1992), p. 241-255.

${ }_{133}$ BENJAMIN, Antonio Herman, Código Brasileiro de Defesa do Consumidor, $5^{a}$ Ed., Ed. Forense Universitária Rio de Janeiro, 1997, p.210-211.

134 Assim DALL'AGNOL, op. cit,, p. 12 e 13, que reproduz o projeto inicial do Parágrafo único do Art.2 do $C D C$ : "Equipara-se a consumidor a coletividade de pessoas, ainda que indetermináveis, que se encontre sujeito ou propensa a intervir nas relações de consumo" (p. 11).

${ }^{135}$ Assim inclui Antônio Herman BENJAMIN um título específico em seus comentários "A suficiência da exposição", op. cit., p. 211.

Revista da Faculdade de Direito da UFRGS, v. 19, Março/2001 do princípio da vulnerabilidade, basilar do CDC e afastar aqueles que, por não vulneráveis, não estão "expostos" às praticas comerciais mencionadas no CDC. A pessoa jurídica ainda mais quando atua na sua área de atividade profissional, não se beneficia da presunção geral de vulnerabilidade do Art. 4,I do CDC (válida somente para pessoas físicas), mas pode provar sua vulnerabilidade in concreto, o mesmo valendo para o Art. 29 do CDC. ${ }^{136}$

Como afirma Dall'Agnol, a pluralidade de sujeitos protegidos assegurada pela técnica de equiparação é grande, mas não generalizante e ilimitada: "Confira-se o que ocorre com o Art. 2 , parágrafo único, o Art. 17 e, sobretudo, o Art. 29. Nâo parece exagerado, porém, antes recordar que "equiparar", segundo os dicionaristas, tem o sentido de "igualar", ordinariamente o de "igualar em sorte, em condição. Não se pense, porém, que em razão disso, se amplia, sem mais, o universo dos destinatários. A correta interpretação do Art. 29, sobre não possibilitar desconsideração para com o corpo legislativo em que está inserido, passa, como de ordinário pelo que lhe é nuclear - o verbo. Quem está exposta é a pessoa que não se encontra, diante de outrem, em pé de igualdade real. Está exposto o pequeno figurante do negócio jurídico diante do grande....em outros termos, estende-se a rede protetiva àquele que se encontra em situação de vulnerabilidade - de modo restrito, pois limitada ao conjunto de regras que compreendem os capítulos Ve VIpouco relevando que não haja relação estrita de consumo. $" 137$

As definições de consumidor do CDC visam justamente equi parar para incluir. $O$ ter ceiro pode ser o garantidor, que antes não aparecia e poucos direitos possuía. $\mathrm{O}$ garantidor

${ }_{136}$ Assim nos manifestamos, MARQUES, Contratos, p. 155

${ }_{137}$ DALL'AGNOL, p. 9 (primeiras frases) e p. 13 (onde consta, por erro, a expressão "só", corrigida na citação). era o fiador, o avalista. Bem, agora ele é consumidor, consumidor equi parado. A definição de consumidor terá que incluir esses sujeitos de direitos. $\mathrm{E}$ o mais interessante é que estes novos sujeitos de direito possuem direito fundamental à proteção, têm direito a não ver violada a sua dignidade, a sua honra, o seu patrimônio, possuem também os mesmos direitos contratuais (mesmo se não concluíram os contratos) que os contratantes diretos (veja Art. 20 do CDC) e os mesmo direitos processuais para defender seus direitos (Art. 81 e 83 do CDC). São novos sujeitos de direito "perfeitos", "pós-modernos", mesmo a coletividade, difusa e o grupo. No CDC não houve graduação ou limitação de direitos, se o consumidor é stricto sensu ou equi parado (exceção feita ao Art. 51, I in fine do CDC). Isto leva a superação do status do terceiro e ao pleno reconhecimento de direitos do consumidor para estes, se em relações de consumo. Em resumo este pluralismo de sujeitos muda o direito civil , porque muda o direito das obrigaçōes para incluir a proteção plena destes novos sujeitos.

II- CAMPO DE APLICAÇÃO MATERIAL E AS RELAÇÕES DE CONSU. MO ENVOLVENDO SERVICCOS: ANÁLISE DO OBJETO E FINALIDADE DESTAS RELAÇÕES PLURAIS E "IMATERIAIS"

O CDC oferece uma definição bastante ampla de serviço em seu art. $3^{\circ}$, $\S 2^{\circ}$ e regula todas as "relações de consumo" (Art. $4^{\circ}$ ), que envolvam serviços remunerados (direta ou indiretamente). O espírito do CDC é aberto (interface do Art. $7^{\circ}$ e solidariedade do $\S$ único do Art. $\left.7^{\circ}\right)$ e expansivo subjetivamente, pois ex vi lege amplo o suficiente para incluir um grande número e todas as espécies de relações de consu- 
mo envolvendo serviços, relações contratuais (Art. 20), pré-contratuais (Art. 30, 31, 34, 39, 40, 84), pós-contratuais (Art. 9, 10,42 e 43) e extracontratuais ex delicto(Art. 14), como também se pode notar nas amplas definições de consumidor (Art. $2^{\circ}$ e $§$ único do Art. $2^{\circ}$ e Art. 17 e Art. 29 do CDC), de fornecedor de serviços (art. $3^{\circ}$ e $\$ 2^{\underline{0}}$ do Art. $3^{\circ}$ do $\mathrm{CDC}$ ) e na norma objetivo ${ }^{138}$ do Art. $4^{0}$, (especialmente incisos I, III, V e VI)

Esta lei consumerista regula assim todo o fornecimento de serviços no mercado brasileiro e as relações jurídicas dai resultantes, mesmo os serviços prestados sem prévia solicitação ou autorização (Art. 39, III e VI do CDC), exigindo apenas "remuneração" do serviço $\left(\$ 2^{\circ}\right.$ do Art. $3^{\circ}$ do $\mathrm{CDC}$ ). Tal remuneração, como a jurisprudência está a indicar, pode ser direta ou mesmo indireta, fato cada vez mais comum no mercado de consumo complexo atual. ${ }^{139}$

A. Objeto da relação de serviço no CDC

O objeto dos negócios jurídicos não são coisas, corporais ou imateriais, mas sim vemos hoje como objeto as prestações, o prometido e

138 Expressão de Eros Roberto Grau, veja Grau Roberto Interpretando o código de Defesa do Consumidor algumas notas, in Revista Direito do Consumidor, vol. 5, p. 183 e seg.

a $O$ movimas notas, in Revista Direito do Consumidor, vol. 5, p. 183 e seg. " movimento da análise econômica nos Estados Unidos alerta-nos para a falácia "econômica" dos chamados "serviços", "utilidades" ou promessas "gratuitas", que não passaria de uma superada ficção jurídica. O que parece juridicamente gratuito, nos alertam mesmo os conservadores e radicais autores deste movimento de Chicago, é economicamente baseado na certeza da remuneração indireta, na interdependência de prestares futuros e atuais (sinalagma escondido), no estado de catividade e de dependência que um dos parceiros fica reduzido e no lucro direto e indireto do outro. Veja, ciando Richard A. Posner, meu parecer, Relação de consumo entre os depositantes de cadernetas de poupança e os bancos ou instituiçôes que arrecadam a poupança popular, in Revista dos Tribunais 760, p. 127.

Assim ensina COSTA JUNIOR, p. 41.

Segundo Domingues de Andrade, em um sentido amplo, "Felação jurídica é toda a situação ou relação da vida real (social) juridicamente relevante (produtiva de conseqüências jurídicas), isto é, disci plinada pelo Direito" e em um sentido estrito, apenas "a relação da vida social disciplinada pelo Direito, mediante a atribuição a uma pessoa (em sentido jurídico) de um direito subjetivo e a correspondente imposição a outra pessoa de um dever ou de uma sujeição. "ANDRADE, Manuel A. Domingues de, Teoria Geral da Relação Jurídica, vol. 1, Reimpressão do original de 1944, Almedina, Coimbra, 1997, p. 2.

${ }_{142}$ Assim o mestre da UFRGS COUTO E SILVA,Clóvis, A obrigação como processo, Ed. Bushtasky, São Paulo, 1976, p. 156, ensinando que a obrigação de fazer tem como objeto da prestaçâo a própria atividade, já a obrigação de dar tem como objeto uma coisa ou direito.

Revista da Faculdade de Direito da UFRGS, v. 19, Março/2001 jurídico cuja obrigação princi pal fosse um fazer (opus facere), em contraposição às obrigações de dar ou ao fornecimento de produtos no mercado. As análises latino-americanas preferem valorar o resultado, o direito/poder resultante do negócio jurídico. ${ }^{143}$ Serviço seria assim o negócio através do qual o titular adquire a faculdade de exigir de outra pessoa uma atividade ou utilidade de conteúdo patrimonial (ius in personam), direito de crédito ou obrigacional, a se contrapor aos direitos reais (ius in re) geralmente resultantes das obrigações de dar.

Ambas as análises estão corretas e presentes sem dúvida em nosso $\mathrm{CDC}$, mas pareceme necessário inicialmente frisar dois problemas. De um lado, visualizamos hoje - em virtude do princípio criador, limitador e hermenêutico da boa-fé (objetiva) ${ }^{144}$ - as obrigações como processos de cooperação no tempo, como feixes de deveres de conduta e de prestação direcionados a um só bom fim, o cumprimento do contrato. ${ }^{145}$ Nesta visão dinâmica da obrigação, concentrar-se em apenas uma das "condutas", em uma das "prestações" é reduzir o espectro, uma vez que - se durar - muitas serão as "prestações princi pais" no tempo, sem esquecer que, na complexidade da vida atual, os fazeres são múlti plos, múlti plos são os "dares" para satisfazer uma só necessidade de consumo e, acima de tudo, hoje já não está mais certo qual a prestação é principal.

Certo é que a prestação princi pal é aquela característica, característica daquele negócio,

geralmente a que não envolva apenas o pagamento ou transferência de quantias, a exceção dos contratos bancários e financeiros. A dúvida hoje é saber se "principal" para o consumidor é o dever de prestação (realizar um tratamento médico, por exemplo), ou é o cumprimento de um dever anexo (informar os riscos do tratamento e opções para permitir a escolha) ou de um dever acessório (ministrar corretamente remédio, alcançar asseio e precisão nos uso dos instrumentos e curativos) ou todo este conjunto unido é a realização das expectativas do consumidor, causa do contrato, logo objeto da prestação. A complexidade atual perturba a definição de serviço pelo resultado concreto alcançado, a maioria dos negócios envolvendo serviços, envolvem apenas direitos pessoais, mas certo é que de um serviço pode resultar hoje um direito real acessório, como por exemplo no caso dos contratos de time-sharing ou multi propriedade, assim como o direito real de uso, no caso do, leasing.

Data venia, prefiro as análises germânicas que geralmente iniciam pela pretensão (Anspruch) resultante do negócio. ${ }^{146}$ Assim, serviço seria o negócio jurídico que propiciar ao titular ou que envolver a prestação de um fazer economicamente relevante, de um ato ou de uma omissão útil e interessante no mercado de consumo, de uma atividade remunerada direta ou indiretamente, um fazer imaterial e principal, que pode ou não vir acompanhado ou complementado por um dar ou pela criação ou entrega de bem material acessório a este fa-

1*3 Boa revisão em COSTA JUNIOR, Olímpio, A relação jurídica obrigacional, Ed. Saraiva, São Paulo, 1994, p. 1 a 7.

I* Sobre as funções do princípio da boa-fé, veja obra recente de MARTINS-COSTA, Judith, A Boa-fé no Direito Privado, Ed. Revista dos Tribunais, 1999, p. 409 e seg.

145 Veja, por todos, LARENZ, Bd.I, p. 26 e seg. e, em português, COSTA JÚNIOR, p. 56 e seg.

${ }_{146}$ Assim também $L O B O$, Paulo Luiz Netto, Responsabilidade por vício do produto ou do serviço, Brasília Jurídica, Brasilia, 1996p. 83 e seg. Para um bom repassar da evolução da doutrina alemã, das teorias chamadas "personalistas" às "patrimonialistas" das obrigaçôes, veja TIMM, p. 76 a 80.

Revista da Faculdade de Direito da UFRGS, v. 19, Março/2001 
zer princi pal, fazer que é, em verdade, a causa de contratar e a expectativa legítima do consumidor frente ao fornecedor. A diferença em concentrar-se na pretensão e não na prestação é o grau de abstração. Prestação é algo concreto que pode acontecer ou não no caso em estudo (não acontece em caso de insolvência, po exemplo); representa assim algo do mundo do fatos, um dar ou um fazer que modifica primeiro os fatos e depois o mundo do direito. Preten são é uma pura abstração jurídica, é criação do direito para indicar que algo vai mudar, que alguém vai "pretender" uma utilidade qualquer e conseguirá ou que pelo menos o direito va protegê-lo (ação em direito material). Pretensão indica que o mundo do direito (plano da eficácia) já está outro em virtude daquele vínculo criador da pretensão titulada. Concentrar-se nas pretensões de cada uma das partes, aquilo que cada um pretende na relação jurídica, facilita "entender" o negócio, sua causa, sua finalidade de consumo, as expectativas legítimas nascidas pela confiança despertada no consumidor pelo fazer do fornecedor.

Consideraremos que a relação jurídica de consumo é de serviço, sempre que, no plano da eficácia, a pretensão dela oriunda for um fazer, uma atividade por parte do fornecedor. Este pensar permite, por exemplo, que em contratos complexos, como os de multi-propriedade, os de planos de saúde ou os contrato múlti plos bancários, considere-se a intenção do consumidor, suas expectativas legítimas como mais importantes do que a natureza de dar ou fazer da efetiva prestação cumprida ou realizada in concreto. Assim, se in concreto, no caso de multi-propriedade, a prestação efetiva foi um dar ou um direito real, mesmo assim a pretensão do consumidor era um serviço complexo, se no caso do plano de saúde, a prestação desta vez foi um organizar um hospital, que ministrou apenas remédios, coisas, bem a pretensão do consumidor foi deslocar riscos futuros de saúde, propiciar sua internação no hospital, receber o tratamento (fazer ou dar) necessário; se no caso dos contratos com bancos múltiplos, a prestação foi um dar dinheiro em mútuo, a pretensão do consumidor era manter-se homo economicus, com crédito (abstrato) quando necessita-se, com uma conta (grupo de fazeres contábeis e de administração) naquele grupo bancário

Concluindo, hoje, com os contratos complexos há um sem número de "prestações", de dar e de fazer. Como ninguém duvida que as eficácias das sentenças cíveis são sempre múltiplas, declaratórias e constituitivas ao mesmo tempo, também ninguém mais duvida que as relações contratuais de fornecimento de serviço e de produtos (muitas vezes imateriais) hoje se misturam. A distinção está justamente na confiança despertada, na pretensão do consumidor, no fim principal que visa alcançar. É esta pretensão que dirá ao intérprete qual é a eficácia prevalente da sentença, qual é a natureza "prevalente" do contrato, se uma pretensão princi pal prevalente de dar produto (material ou imaterial) ou de fazer (serviço abstrato ou com resultados materiais).

2. A conexidade de prestações nos atuais serviços complexos

Um outro fenômeno a destacar, que bem poderia ser examinado quando do exame da finalidade, mas parece-nos que sua análise junto ao objeto da relação de serviços é mais útil a uma visão real da multiplicidade e complexidade das relações de serviço atuais, é a conexidade. Não podemos mais examinar as relações de serviço e deixar de examinar os chamados "atos de consumo por conexidade" ou relações de consumo acessórias. Destaquese, pois, que hoje podemos classificar as relações de consumo como relações de consumo principal (por finalidade de consumo), relações de consumo por conexidade, por catividade, por acidente (art. 17 do $\mathrm{CDC}$ ) e incidentais (Art. 29 e $\S$ único do art. $2^{\circ}$ do CDC).

Para a conexidade das relações a explcação é simples: na sociedade moderna por vezes as relaçōes contratuais são tão conexas essenciais, interdependentes e complexas que impossível distinguí-las, realizar uma sem a outra, deixar de realizá-las ou separá-las. E assim, se uma das atividades (ou fins) é de consumo acaba por "contaminar", por determinar a natureza acessória de consumo da relação ou do contrato comercial. Um bom exemplo, foi a te lefonia a algum tempo atrás, em que para ad quirir uma linha telefônica tinha o consumido de comprar açōes conexas. ${ }^{147} \mathrm{O}$ consumidor/ usuário de serviços telefônicos transformava-se em acionista da empresa pública, mas era em verdade (e finalisticamente) destinatário final dos serviços da empresa. Era esta a sua causa inicia e final (o que lhe movia e o que aspirava alcançar no final), era este uso do telefone que ele queria atingir, sendo a titularidade das ações conexas apenas uma imposição legal da época. Há que se dar destaque a esta conexidade d consumo, pois é esta determinante da interpretação (do regime e dos efeitos) que se dará ao

contratos e relações acessórias (talvez não de consumo stricto sensu).

Mister, pois estudar e estar ciente das redes de contratos, as redes de consumidores e os atuais contratos coletivos ou sistêmicos. A união de contratos, seu encadeamento em redes, cadeias de fornecimento, formação de grupos de consumidores alvo é o novo meio que se utiliza o mercado para a satisfação de um interesse, o qual não se poderia realizar através das figuras típicas contratuais existentes e do modo de negociação e contratação clássico, mas que o encadeamento/simultaneidade de contratos permite. ${ }^{148}$

A conexidade é, pois, o fenômeno operacional econômico de multiplicidade de vínculos, contratos, pessoas e operações para atingir um fim econômico unitário e nasce da especialização das tarefas produtivas, da formação redes de fornecedores no mercado e, eventualmente, da vontade das partes. ${ }^{149} \mathrm{Na}$ doutrina, ${ }^{150}$ distinguem-se três tipos de contratos conexos de acordo com as suas características básicas de possuírem fim unitário (elemento objetivo), de se existe uma eventual vontade de conexão ou união (elemento subjetivo) ou se a

${ }_{147}$ Veja decisão sobre o caso na jurisprudência, in Revista Direito do Consumidor, vol. 29, p. 173 e seg: "....a Lei 8.078,90 estabelece, amplamente, o alcance de suas disposiçóes... quando houver dano ao consumidor, sendo este equiparado a coletividade de pessoas, ainda que indetermináveis, que haja intervindo nas relaçôes de consumo, entre os quais se inserem, sem nenhuma distinção, os usuários, adquirentes de linha telefônica, e os acionistas ...na realidade e no caso do contrato de participação financeira em investimentos para expansão e melhoramentos dos serviços públicos de telecomunicaçōes, essas relą̧ôes estão atreladas $e$ intimamente ligadas..." (juiz de Direito Osmar Bocci, São Paulo, j. 22.09.98, p. 176,177 e 178)

${ }_{148}$ Assim LORENZETTI, Ricardo, Redes Contractuales: Conceptualización juridica, relaciones internas de colaboracion, efectos frente a terceros, in Revista da Faculdade de Direito UFRGS, Sintese, , v. 16, 1999, p. 161 e seg., também publicada in Revista Direito do Consumidor, vol. 28 (1999), p. 22 e seg.

${ }_{149}$ Veja por todos, LORENZETTI, p. 22 e seg.

${ }_{150}$ Aqui aproveitamos dos ensinamentos da doutrina italiana sobre "collegamento"(MESSINEO, GANDOLFI, GALGANO), da doutrina francesa sobre "groupes de contrats" (TEYSSIÉ, LARROUMET), da doutrina alemã sobre "komplexe Langzeitverträge" (MARTINEK) e "verbundene Geschäfte" (MEDICUS), da doutrina argentina sobre "redes contractuales" (LORENZETTI) e sobre "conexidad negocial" (MOSSET doutrina argentina sobre "redes contractuales" (LORENZETTI) e sobre "conexidad negocial" (MOSSET
ITURRASPE), da doutrina norte-americana sobre "relational contracts" (MACNEIL), da doutrina inglesa do "collateral contracts" (ATTYAH) e da doutrina brasileira sobre coligamento e contrato relacional (Orlando GOMES e Ronaldo PORTO MACEDO), em classificação que esperamos unificadora.

Revista da Faculdade de Direito da UFRGS, v. 19, Março/200 
conexão foi determinada por lei (compra e venda com financiamento do Art. 52 do CDC) quais sejam:

1. Grupos de contratos, contratos vário que incidem de forma paralela e cooperativa para a realização do mesmo fim. Cada contrato (por exemplo, contratos com um banco múltiplo popular e um consumidor com conta corrente) tem um objetivo diferente (cartão de extratos, crédito imediato limitado ao cheque es pecial, depósito bancário simples) mas concorrem para um mesmo objetivo (conta corrente especial do consumidor) e somente unidos podem prestar adequadamente..$^{15}$

2. Rede de contratos, em que cada contrato tem sucessivamente por objeto a mesm coisa, o mesmo serviço, o mesmo objeto da prestação. É a estrutura contratual mais usada pelo fornecedores ao organizar a suas cadeias de prestação ao consumidor com fornecedores direto e indiretos, como no caso do seguro-saúde, tam bém usada nas colaborações entre fornecedores para a produção (e terceirizações) e distribuição no mercado. ${ }^{152}$

3. Contratos conexos stricto sensu, são aqueles contratos autônomos que por visarem realização de um negócio único (nexo funcional), celebram-se entre as mesmas partes ou entre partes diferentes e vinculam-se por esta finalidade econômica supracontratual comum, identificável seja na causa, no consentimento, no objeto ou nas bases do negócio. Assim, se a finalidade supracontratual comum é de consumo, todos os contratos são de consumo por conexidade ou acessoriedade.

Aqui o círculo se fecha e a nova visão do objeto da relação influencia diretamente a de sujeito desta. Assim, por exemplo, há relação ou contrato de consumo conexo na relação entre conveniado (mesmo que dependente) ligado a sindicato/empresa com contrato coletivo (contrato em grupo) e fornecedora de planos e seguros de assistência à saúde (contratos coligados por função econômica única). $O$ mestre argentino Ricardo Lorenzetti ensina a importância desta visão amplificadora, frisando que neste caso há causa contratual individual e a causa sistemática ou sistêmica, que une o grupo, mencionando que são duas distintas, logo que há individualidade de direitos e interesses apesar da rede ou grupo organizacional de contratos, o que há é um limite mais claro ao não poder prejudicar os interesses do grupo. em outras palavras, se no plano da existência tratase de relação de consumo por conexidade haverão reflexos claros no plano da eficácia, com o nascimento de direitos e deveres para um maior número de partici pantes. ${ }^{153}$

Como ensina Lorenzetti, ${ }^{154}$ considerado o fenômenos das cadeias de fornecimento, das redes coligadas de contratos principais e aces-
${ }_{151}$ Assim concorda LORENZETTI, p. 47, frisando a garantia e responsabilidade pelo êxito comum. Na XVI Jomada Nacionales de Derecho Civil, em Santa Fé, Argentina, foi dada nova denominação, desta vez de "sistema de contratos", que seria "un grupo de contratos individuales conectados por una operación económica diferente de cada uno de los vínculos individuales"(Conclusões ainda inéditas).

${ }_{152}$ Assim concorda o grande jurista argentino em sua novel obra, MOSSET ITURRASPE, Jorge, Contratos Conexos, Ed. Rubinzal-Culzoni, Buenos Aires, 1999, p. 119 e seg. Destaca o autor, op. cit., p. 46, que

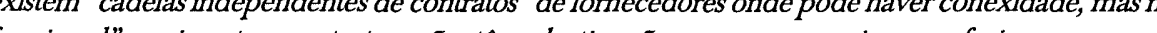
funcional, pois estes contratos não têm destinação comum, por isso preferimos a expressão de

L33 Assim LORENZETTL, Ricardo, Redes Contractuales: Conceptualización juridica, relaciones internas de colaboracion, efectos frente a terceros, in Revista da Faculdade de Direito UFRGS, Sintese, , v. 16, 1999, p. 161 eseg. 154 LORENZETTI, op. cit., p. 198

Revista da Faculdade de Direito da UFRGS, v. 19, Março/2001 sórios para a prestação de uma finalidade coletiva de consumo, da organização de grupos de consumidores para melhor distribuição do consumo, o direito hoje deve considerar que em se tratando de relação de consumo (art. $3^{\circ} \mathrm{do}$ CDC) não há mais terceiro, "vítima" ou "beneficiário", há consumidor (art. $2^{\circ}, 17$ e 29 do CDC). Assim reflexamente, todo o "consumidor", assim considerado pelo CDC, é parte legítima para exercer seus direitos básicos (de fundo constitucional) assegurados no art. $6^{\circ} \mathrm{do}$ $\mathrm{CDC}$, inclusive o de combate às cláusula abusivas, práticas abusivas, de acesso à justiça de inversão do ônus da prova. A ele foi dada uma nova "pretensão" frente a este fornecedor. Esta nova visão qualificada e ampliadora da relações de consumo é necessária para uma boa aplicação do CDC. Assim, pode ser um indicador da conexidade de relações contratuais (de consumo) e da vulnerabilidade in concreto por exemplo, a posição de catividade, sujeição e dependência no tempo que esteja reduzido um dos co-contratantes. ${ }^{155}$ Assim, por exemplo, se alguém é cliente de um grupo bancário e lá possui sua conta especial, muitas vezes é levado a ter uma conta poupança anexa a sua contadepósito, ou uma poupança de determinada monta para poder obter um crédito, ou uma cobertura de seguro (consumo conexo). Com os bancos múlti plos populares este estado de "catividade", de interdependência de uma série

de negócios entre os mesmos parceiros passou a ter certa relevância jurídica, pois o parceiro mais fraco tem dificuldade de sair do vínculo $\mathrm{e}$ o parceiro mais forte tem facilidades de exigir do outro qualquer modificação (novação/cessão/denúncia) ${ }^{156}$ em um vínculo menos importante, desde que mantenha o vínculo mais importante para o consumidor. A catividade é interdependência entre parceiros e vínculos múlti plos no tempo, a conexidade é o método de comercialização e marketing, é a conseqüência, que hoje pode ser facilmente fotografada no mercado nacional. ${ }^{157}$

B.Finalidade da Relação de serviço no $\mathrm{CDC}$

1. A finalidade intrínseca das relações de consumo

Em geral, a finalidade econômico-social de um ato humano é elemento qualificador e categorizador deste, nas relações de consumo o mesmo ocorre, só que com intensidade ainda maior. ${ }^{158}$ Assim é que, antes de analisarmos as garantias dos consumidores na prestação de serviços e sua evolução em relação as garantias existentes nas relaçōes civis outras, gostaria de frisar que a relação de consumo é finalista, sua finalidade intrínseca e particular é o "consumo"

${ }^{155}$ Em magistral artigo, conclui Ronaldo Porto Macedo: "1. A relação de consumo ensejadora da proteção jurídica do CDC se configura independente da existência de uma contratação direta de consumo. 2. Haverá relação de consumo sempre que o contrato entre empresas para o fornecimento de bens ou servicos atinjam consumidores fnais trabalhadores vulnerávis e não envolva a aquiscão de insumos ou bens depror bens de produçâa.... 4. Os planos de saude e de previencia privada pagos integralmente pelo empregador em favor de seus funcionários estáo submetidos ao CDC naquilo em que afetarem os interesses dos consumidores."(MACEDO, Ronaldo Porto, Relação de consumo sem contratação de consumo direta. Quando o empresário paga a conta, in Revista Direito do Consumidor, vol. 27, p. 42 e seg:).

156 Concluíram sobre o estado de sujeição/submissão/catividade estudos no mundo inteiro, veja LOMNICK, Eva, Unilateral variation in banking contract: an unfair term ? " $H O W E L L S$, Geraint, Seeking social justive financial services, Kluwer Int, Haia, 1999, respectivamente p. 99 e seg. e p.239 e seg.

${ }_{157}$ Veja o nosso, Contratos bancários em tempos pós-modemos, in Revista Direito do Consumidor, vol. 25, p. 21. ${ }^{158}$ Assim LORENZETTI, Tratado de los contratos, p. 23.

Revista da Faculdade de Direito da UFRGS, v. 19, Março/2001 
lato sensu. Já que estamos aqui no exame dos elementos da relação jurídica, mister destacar aqui como característicos destes serviços de consumo seu elemento finalístico. E esta finalidade que move o consumidor, esta é a base do negócio, é a pressuposição objetiva que movimenta estes agentes econômicos no mercado. Falho seria examinar a relação de consumo sem ter em conta a sua finalidade, mais especificamente as expectativas agora legítimas dos consumidores que entram, se expõe ou intervêm nestas relações jurídicas envolvendo serviços. ${ }^{159}$

A relação de consumo concretiza-se na sua causa ( $Z$ weckursache), causa inicial e final, na sua finalidade, que é naturalmente de consumo. Esta certeza ajudará em muito o exame do plano da existência, isto é, a caracterização da relação envolvendo serviços como de consumo ou não, pois é sempre possivel perguntar se a causa (inicial e final) principal, a causa do contrato acessório de consumo ou por conexidade (até mesmo a causa do acidente) foi de consumo ou de produção. Para entender um fenômeno, a natureza de um ato ou relação, a primeira pergunta a se realizar é sobre o porquê deste fenômeno ("Warum"). ${ }^{160} \mathrm{Na}$ interpretação das normas, o porquê é questionado enquanto ratio legis ("Grund" e " $Z$ weck", interpretação teleológica). Já, na aplicação das normas aos fenômenos da vida, o porquê é

questionado enquanto base e causa ("Grund" e "Ursache") para a atuação do ser humano. O fenômeno em si (ato ou relação) é visto como simples resultado (consequentia, effectus). Assim, da análise das caraterísticas do fenômeno é que se descortinará sua causa, sua base, o seu porquê. ${ }^{161}$

Efetivamente causa e effectusrelacionam se entre si, são um o pressuposto do outro, mas somente a causa é elemento intrínseco, básico do fenômeno, ${ }^{162}$ no caso, da relação jurídica. Segundo Roberto Senise Lisboa, o "Código de Defesa do Consumidor adotou a doutrina da causa na relação de consumo, ao preceituar que o consumidor é "o destinatário final do produto ou serviço'." ${ }^{63}$ Esta diferenciação entre efeitos ("Wirkungen"), conseqüências materiais e fáticas do ato ("sein"), e a causa, em especial a causa finalis (" $Z$ weckursache"), aquilo que se pretendia alcançar com o ato e a causa efficiens, causa inicial ("Wirkursache"), aquilo que movimentou o indivíduo a contratar, pode ser muitas vezes útil para caracterizar um ato como de consumo. Em outras palavras, os efeitos estão no mundo dos fatos (o que é,"sein") a causa, a base, a finalidade está no mundo do direito (o esperado" sollen"). A base contratual, a sua finalidade, é característica ou elemento intrínseco da relação juridicamente relevante, estudada no plano da existência. Assim, por

${ }^{159}$ Assim também LISBOA, Roberto Senise, A relação de consumo e seu alcance no direito brasileiro, Coleção Saber Jurídico, Ed. Oliveira Mendes, São Paulo, 1997, p. 33: "Os elementos intrínsecos do negócio jurídico "cau" senua finalidade, o motivo ou o objetivo pelo qual um sujeito de direito acaba por firmar o negócio jurídico."

${ }_{100}$ Assim LAUN, Rudolf, Der Satz vom Grunde- Ein System der Erkenntnistheorie, 2.Ed, Tuebingen, 1956, $p$ 58. Trata-se, segundo Aristóteles, do início de toda investigação e base do conhecimento dai resultante ("oberste Anfang des Wissens")

${ }^{10 t}$ LAUN, op. cit, p. 51 e seg.

${ }_{102}$ Estamos utilizando os conceitos de base (Grund) e causa (Ursache) como sinônimos, de forma a facilitar e reduzir a análise, mas estes são em sentido estrito e filosófico, diferenciáveis, veja detalhes em LAUN, op. cit, p. 52 .

${ }^{163}$ LISBOA, op. cit, p. 34

Revista da Faculdade de Direito da UFRGS, v. 19, Março/200 "causa" significa, em língua portuguesa, a razão, o motivo, a origem. No universo jurídico, a causa é exemplo, uma relação jurídica que vise beneficiar consumidores (equi parados) com planos de saúde, tem causa de consumo, não impor tando como aparecerá no mundo dos fatos, por exemplo, contrato assinado entre o empresário que emprega trabalhadores (beneficiários junto com seus dependentes do plano) e uma cooperativa. ${ }^{164}$

Relembre-se, por fim, também que muitas são as relações cativas de longa duração envolvendo serviços. Tratam-se de relações de serviço que se prolongam no tempo, não por sua natureza intrínseca, mas por sua característica finalística. Assim, por exemplo, quem possui uma conta corrente está vinculado a um fornecedor bancário por anos e geralmente concluirá com este mais de um negócio jurídico neste tempo (seguro de vida, de acidentes, de roubo do cartão, de saúde etc.), outro bom exemplo é a poupança popular, quem possui uma poupança deixará lá seu dinheiro por mais de 30 dias, apesar de poder retirá-lo antes, justamente porque a finalidade do contrato prevê a remuneração direta do consumidor somente ao fim deste período.

A relação de consumo concretiza-se na sua causa, causa inicial e final, na sua finalidade, que é naturalmente de consumo. Esta certeza ajudará em muito o exame do plano da exis- tência, isto é, a caracterização da relação envolvendo serviços como de consumo ou não, pois é sempre possível perguntar se a causa (iniciale final) principal, a causa do contrato acessório de consumo ou por conexidade (até mesmo a causa do acidente) foi de consumo ou de produção. ${ }^{165}$

Concordam com esta necessária diferenciação mesmo autores maximalistas. Roberto Senise Lisboa afirma: "Daí porque parece razoável o entendimento segundo o qual o legislador, apesar de não ter se preocupado com a dicotomia bem de custeio-bem de insumo, fixou a diretriz da diferenciação da relação de consumo e da relação ordinária na causa determinante. Caberá, pois, à doutrina e à jurisprudência, na análise de cada caso a elas submetido, explorar a noção de relação de consumo sempre à luz da doutrina da causa das obrigaçôes, para dirimir a questão..."166 Por sua vez, afirma Luiz Antônio Rizzatto Nunes: “...o CDC não regula situaçôes nas quais, apesar de se poder identificar um "destinatário final", o produto ou serviço é entregue com a finalidade específica de servir de "bem de produção" para outro produto ou serviço e via de regra não está colocado no mercado de consumo como bem de consumo, mas de produção; o consumidor comum não o adquire." 167 O necessário exame da finalidade/causa da relação contratual 16t Veja MACEDO, Relação de consumo sem contratação de consumo direta, p. 42 e seg.

165 Assim também José Reinaldo de Lima Lopes, distingue entre "crédito ao consumo" e "crédito à produção". Afirma o professor da USP: "Desnecessário dizer que o primeiro está abrigado no Código de Defesa do Consumidor, o segundo não. Isto não significa que o tomador de crédito não ao consumo esteja desprotegido: significa apenas que o seu sistema de proteção não é o de consumo. O crédito ao investidor dá-se sob a forma de financiamentos e muitas vezes de repasses de fundos públicos ou estrangeiros, desconto, faturização, adiantamentos sobre contratos de câmbio, operaçōes de garantia etc. Não creio que seja necessário - e nem juridicamente correto - usar o Código de Defesa do Consumidor para proteger tomadores de empréstimo para investimento." Veja LOPES, José Reinaldo de, Consumidor e Sistema Financeiro, in Revista Direito do Consumidor, vol. 22 (1997), p. 95. 166 LISBOA, Relação, p. 30, que critica, como antes mencionado, o uso das expressôes "bem de produção",
"bem de consumo" e de "bem de custeio" "bem de insumo", exame da vulnerabilidade, realizando entâo "bem de consumo" e de "bem de custeio" "bem de insumo", e exame da vulnerabilidade, realizando entấo este exame material do contrato ou da causafinalidade do contrato para chegar à Justiça no caso concreto de
tratamento desigual dos desiguais.

167 RIZZATTO NUNES, Luiz Antonio, Comentários ao CDC, Saraiva, São Paulo, 2000, p. 87 e 88.

Revista da Faculdade de Direito da UFRGS, v. 19, Marco/2001 
para a eventual aplicação do Art. $2^{\circ}$ do CDC peloJudiciário, é, pois, uma unânimidade entre finalistas e maximalistas.

2. Finalidade negocial e remuneração direta ou indireta dos serviços

Seria impossível finalizar esta análise da "finalidade" nas relações de serviço, sem enfrentar mais afundo o tema da expectativa legítima do fornecedor de ser remunerado, como elemento categoriais dos contratos de serviço regidos pelo CDC no plano da existência: só será serviço de consumo a atividade "remunerada" (Art. $3 \S 2^{\circ}$ do CDC). Mister aqui frisar a evolução que o CDC propõe entre "onerosidade" "remuneração" e que nem sempre está sendo compreendida pela Jurisprudência.

Quanto a este aspecto, vale frisar mais uma vez que o CDC não utiliza-se da distinção clássica de contratos onerosos de prestação de serviços e de contratos "gratuitos". O que pode inexistir no sistema do CDC é a "obrigação de pagamento" (veja expressão literal do Art. 39,III e §único no CDC). Pagamento é apenas uma das formas (diretas) de remuneração.

Frise-se assim que a expressão utilizada pelo Art. $3^{\circ}$ do $\mathrm{CDC}$ para incluir todos os serviços de consumo é "mediante remuneração". O que significaria esta troca entre a tradicional classificação dos negócios como "onerosos" e gratuitos, por remunerados e não remunerados. Parece-me que a opção pela expressão "remunerado" significa uma importante abertura para incluir os serviços de consumo remunerados in diretamente, isto é, quando não é o consumdor individual que paga, mas a coletividade (facilidade diluída no preço de todos) ou quando ele paga indiretamente o "beneficio gratuito" que está recebendo. A expressão remuneração permite incluir todos aqueles contratos em que fo possível identificar no sinalagma escondido (contraprestação escondida) uma remuneração indireta do serviço de consumo. aqueles contratos considerados "unilaterais", como o mú tuo, sem problemas, assim como na poupança popular.

Só existem três possibilidades, ou o serviço é remunerado diretamente ou o serviço não é oneroso, mas remunerado indiretamente, não havendo enriquecimento ilícito do fornecedor, pois o seu enriquecimento tem causa no contrato de fornecimento de serviço, causa esta que é justamente a remuneração indireta do fornecedor ou o serviço não é oneroso de maneira nenhuma (serviço gratuito totalmente), $\mathrm{e}$ se for "remunerado" indiretamente haveria enriquecimento sem causa de uma das partes.

A falácia da gratuidade, por exemplo, na poupança popular não resiste ao menor exame da estrutura contratual, pois mesmo se estes contratos de poupança fossem "gratuitos", não seriam nunca sem "remuneração" indireta. Isto é, "gratuito" aqui significa apenas dizer que não há (por enquanto) remuneração aparente e sim, remuneração causal-implícita. O sinalagma contratual está escondido, a remuneração causal está escondida, mas existe e é juridicamente relevante, tanto que, se não existisse, haveria enriquecimento ilícito dos Bancos (condictio indebitt).

Analisando o caso dos contratos de poupança popular, observamos que nunca ninguém aduziu que, em matéria de administração e gestão do dinheiro alheio depositado nas contas de poupança popular, haveria enriquecimento sem causa ou ilícito dos Bancos (ungerechtfertigte Bereicherung). Agora ninguém duvida que os bancos "recebem" remuneração por manterem contas de poupança, se não "enriquecessem" com estes serviços "gratuitos" não os fariam...Há enriquecimento sim, pois lucram com juros de mercado e pagam juros de poupança, mas há causa... contratual, bilateral, sinalagmática, há contra-prestação por serviços prestados, logo, é a relação sinalagmática, legal e causal, que torna este enriquecimento lícito.

Como diriam os autores alemães, se há Bereicherung (enriquecimento) de um, há Leistungkondition (condição de prestação, necessidade de prestar ${ }^{168}$ para este frente ao outro. A questão princi pal é descobrir se a necessidade de prestar (condictio) tem origem contratual $^{169}$, logo, neste caso, a relação contratual é a causa de não necessitar o Banco indenizar pelo enriquecimento que efetivamente atinge ao "operar" com a poupança alheia ou se, por absurdo, a necessidade de prestar (Leistungkondition) teria origem extracontratual, logo, não haveria causa contratual, e consequentemente haveria necessitar indeniza por todo e qualquer enriquecimento sem causa dos Bancos... No caso das contas poupança e do serviço (teoricamente, gratuito) prestado pelos Bancos aos clientes salta aos olhos que há condictio, mas que esta é contratual, sendo assim, não há enriquecimento ilícito, nem sem causa dos Bancos (pois o contrato sinalagmático é a sua causa), há apenas remuneração indireta através deste enriquecimento - repito - legal e contratual.

Comprovar esta afirmação é fácil, basta retirar a causa e repetir o mesmo "fato/ato jurídico" sem causa contratual. Imagine-se um indivíduo, que não fosse um Banco, com o qual -por lei- não poderia haver contrato de poupança popular,e que, por 30 dias, administrasse a poupança alheia e que obtivesse com ela um lucro de 49 e pagasse ao proprietário apenas 2 . Haveria enriquecimento ilícito, sem causa (ungerechtfertigte Bereicherung), haveria a necessidade de prestar (condictio indebiti), de de-

${ }_{108}$ Veja por todos LOEWENHEIT, Ulrich, Bereicherungsrecht, Beck, Munique, 1989, p. 13 e seg.

${ }^{169}$ Assim ensina magistralmente MEDICUS, Dieter, Schuldrecht II, Beck, Munique, 1987, p. 286.

170 Veja detalhes em meu parecer, "Relação de consumo entre os depositantes de cadernetas de poupança e os bancos ou instituiçôes que arrecadam a poupança popular, in Revista dos Tribunais 760, p. 127.

olver o que sem causa ganhou. A única hi póese de não ter de devolver o resto, é que este , quasi-contratualmente - como "remunerapela prestação de serviços de gestão, administração, assunção de riscos etc. Este teste da "implícita, os alemães denominam condictio ob causam finitam. Se a causa contratual desaparecesse ou, no caso, não existisse, o sistema jurídico haveria que, necessariaente, impor a volta ao status quo ante, impedir o enriquecimento ilícito de qualquer das partes. ${ }^{170}$

Hoje, pois, juridicamente, a alegada gratuidade dos serviços não significa falta de remuneração. Também economicamente esta denominada "gratuidade" é ilusória. $o$ justamente o movimento da análise conômica nos Estados Unidos que nos alera para a falácia "econômica" dos chamados "serviços", "utilidades" ou promessas "gratuitas", o que não passaria de uma superada ficção jurídica. O que parece juridicamente gratuito, nos alertam mesmo os coneste movimende Chicago, é economicamente baseado certeza da remuneração indireta, na parceiros fica reduzido e no lucro direto e indireto do outro. O próprio fundador do an' ever make a promise without receiving $n$ exchange something of value from the promisee, whether it be money, a promise

Revista da Faculdade de Direito da UFRGS, v. 19, Março/2001 
of future performace beneficial to the promisor, or something else of value to him? It is temping to answer this question simply by involving 'interdependent utilities'... The approach taken here is that a gratuitous promise, to the extent it actually commits the promisor the promised course of action (an essential qualification), creates utility for the promisor over and above the utility to him of the promised performance. At one level this proposition is a tautology: a promise would not be made unless it conferred utility on the promisor. The interesting question is how it does so. I shall argue that it does so by increasing the present value of an uncertain future stream of transfer payments. "I71

Em decisão do $1^{\circ}$ TACiv.SP, o eminente Relator Juiz Silveira Paulilo afirmava: " $O$ Código de Defesa do consumidor quando define serviço, dispó ser ele qualquer atividade fornecida no mercado de consumo, mediante remuneração, inclusive as de natureza bancária, financeira, de crédito...A caderneta de poupança é, sem dúvida, um serviço colocado à disposição do consumidor pelos bancos, que lucra com isso. $A$ "remuneração" à qual alude a lei não é somente uma contraprestação pecuniária paga pelo interessado, mas qualquer tipo de lucro que se possa extrair da atividade oferecida." ${ }^{172}$

Se a relação de consumo tem como finalidade algum tipo de remuneração, mesmo que indireta do fornecedor está ela incluída no regime do CDC, como comprova até mesmo o Art. 39,III e $\S$ único que visam regular relações "gratuitas", mas claramente de consumo.

\section{CONCLUSÕES}

A teoria finalista, que defendo, nada mais é do que uma interpretação conforme à Constituição (Princípio constitucional da Igualdade e Direito fundamental do cidadão à proteção do Estado, enquanto consumidor - Art. 5 o caput e inciso XXXII da CF/88), interpretação conforme a nova ordem econômica constitucional (Art. 170 da CF/88) e a importância da identificação do sujeito de direitos a tutelar de maneira especial, o consumidor! É interpretação do Art. $2^{\circ}$ do CDC utilizando todos os métodos clássicos de interpretação: literal, lógico-sistemático e teleológico. A teoria contrária -maximalistapropugna uma interpretação apenas literal da expressão "destinatário final", concluindo que basta ser destinatário final fático do produto ou serviço. A origem constitucional do CDC hierarquiza esta lei, a qual materializa direito fundamental (apenas) das pessoas fisicas, e conduz necessariamente o aplicador da lei a interpretação cuidada desta lei especial tutelar. Segundo pensamos, o destinatário final é o que retira o bem ou serviço do mercado ao adquirir ou simplesmente utilizá-lo (destinatário final fático), aquele que coloca um fim na cadeia de produção (destinatário final econômico) e não aquele que utiliza o bem ou seguro para continuar a produzir, utilizando-o como parte, insumo ou garantia da sua produção.

Interpretando-se a expressão legal "destinatário final" no sistema do CDC ou pelo método lógico-sistemático, observamos que este Código positiva os princípios que devem guia a interpretação de suas normas no Art. $4^{0}$ do $\mathrm{CDC}$, reconhecendo a necessidade de proteção do vulnerável (princípio da vulnerabilidade do Art. 4⿳⺈, inciso I do CDC), da boa-fé e do equilíbrio (princípio da boa-fé e proteção da confiança do Art. $4^{\circ}$, inciso III do CDC). Interpretando a expressão "destinatário final" pelo método teleológico ou finalístico, observamo que sua ratio é a proteção do consumidor-final, aquele que retira da cadeia de produção o bem ou serviços, o destinatário final econômico, que não repassa estes custos para terceiros, aquele que não detém os meios de produção, aquele que consome de maneira realmente " $\mathrm{fi}$ nal" e que o valor protegido pela norma é a igualdade, a proteção dos vulneráveis, dos nãoiguais (Art. 4, I e III do CDC). Esta interpretação conforme a Constituição (Art. $5^{\circ}$, XXXII Art. 170 da CF/88 e 48 da ADCT) e conforme os princípios positivados no $\mathrm{CDC}$ para definir o campo de aplicação desta lei (Art. $1^{\circ}, 2^{\circ}, 3^{\circ}, 4^{\circ}$ e $7^{\circ}$ do CDC) destaca a importância da vulnerabilidade do agente para que possa ser considerado consumidor. Defendo que, face ao Art. $2^{\circ}$ do CDC e ao Art. 4, inciso I desta le especial, milita uma presunção de vulnerabilidade para as pessoas fisicas destinatárias finais do serviço. A jurisprudência tem exigido a prova da vulnerabilidade in concreto para que pessoas jurídicas beneficiem-se das regras protetivas do CDC. A equi paração a consumidor por força do Art. 29 do CDC pode beneficiar o não-destinatário final de produtos e serviços, quando contratante, e também à pessoa jurídica. Para beneficiar-se da aplicação do Art. 29 do CDC, a jurisprudência exige hoje a prova de vulnerabilidade in concreto. Efetivamente, a aplicação do Art. 29 do CDC exige que as pessoas por ele equi paradas a consumidores estejam "expostas" a práticas comerciais do outro contratante e só está "exposto" quem é vulnerável, não igual, mais fraco, leigo ou necessitado.

Parece-me comprovada a afirmação de Erik Jayme de que o sujeito de direitos identificado na pós-modernidade qualifica-se quando recebe direitos fundamentais, como aconteceu no Brasil com os consumdiores, e acaba este sujeito por modificar as instituições em que está presente, como o contrato massificado e complexo de serviços atual. As plurais definiçōes de consumidor do $\mathrm{CDC}$ (Art.2, parágrafo único do Art. 20, Art. 17 e Art. 29 do $\mathrm{CDC}$ ) visam justamente incluir os não contratantes, os terceiros beneficiários, os que pagaram direta e indiretamente os serviços de consumo, os terceiros vítimas, os terceiros garantidores, os vulneráveis expostos às práticas comerciais abusivas. Visam definir, com base nos princípios expostos no Art. 4, I e III do CDC, quem é consumidor, visam equi parar para proteger os desiguais. $\mathrm{O}$ sujeito de direitos do CDC (código protetivo apenas deste agente econômico vulnerável, o consumidor) é um sujeito pós-moderno, plural e destruidor dos dogmas contratuais antigos, tais como o efeito inter partes dos contratos e a não conexidade das relaçōes complexas, acabando por superar mesmo a figura do terceiro contratual ao defini-lo como "consumidor" stricto sensu ou equi parado.

171 POSNER, Richard A., Gratuitous Promises in Economic and Law, in The Economics of Contract Law Kronman, Anthony e Posner, Rchard A., Ed. LB, Boston, 1979, p. 46, artigo publicado originalmente in 6 J.Legal Studies 411(1977)

${ }_{172}$ Ap. Civ. 581.830/6, j. 25.04.96, Rel. Juiz Silveira Paulilo, $1^{\circ}$ TACiv.SP.

Revista da Faculdade de Direito da UFRGS, v. 19, Março/2001 